\title{
Alternative Assessment Practices in Science
}

\section{Nida BÜYÜKTOKATLI ${ }^{* a}$, Şule BAYRAKTAR ${ }^{b}$}

${ }^{\text {a }}$ Ministry of Education, Bağlı Primary School, Aksaray/Turkey

${ }^{\mathrm{b}}$ Necmettin Erbakan University, Faculty of Education, Konya/Turkey

\section{Article Info}

DOI: $10.14527 /$ pegegog.2014.006

Article history:

Received 13 July 2013

Revised 11 November 2013

Accepted 27 January 2014

\section{Keywords:}

Science and technology course, Assessment and evaluation,

Assessment and evaluation techniques.

\begin{abstract}
The purpose of this study is to determine whether there is a difference in primary education teachers' and science and technology teachers' frequencies of use of alternative assessment techniques with regard to demographic (gender, branch, professional experience, the graduated school type) variables. The sample of the study consisted of 75 primary education teachers and 40 science and technology teachers most of whom working in Aksaray in 2012-2013 academic year. In this study, a questionnaire developed by researchers was used to collect data. According to the research results, teachers' frequencies of use of alternative assessment techniques showed a significant difference with regard to gender, branch, and professional experience.
\end{abstract}

\section{Introduction}

Assessment and evaluation are important parts of educational process. Whether a curriculum creates the desired effect or not on students' knowledge, skills, and attitudes determined by means of assessment and evaluation. Continuous assessment and evaluation of the educational processes enables educators to identify the problems and take necessary actions at all stages of the process (MEB, 2006).

As an integral part of a curriculum, assessment and evaluation have important role in students' learning. A qualified assessment and evaluation system should be able to reflect what students really know, and provide information about students' processes of learning. The system also should produce ideas about how can students learn better. According to traditional viewpoint, teacher is the only decision maker and the director of assessment and evaluation activities. However, with this type of assessment, it is not possible to observe what processes students go through when learning, and how they analyse information and construct knowledge (Öncü, 2009).

Turkish Education System has been revised by reconstructing teaching programs according to constructivist learning theory as of the 2005-2006 academic year. Parallel with the revised curricula, a number of innovations in the assessment and evaluation practices have been introduced. Accordingly, alternative approaches, which are based more on processes rather than the products of learning, have begun to replace the traditional assessment and evaluation practices. (EARGED, 2006; MEB, 2004).

Teachers assess their students for two primary purposes : (1) monitoring students' learning and make the necessary changes for both individual and for all class members (2) grading students after teaching a semester (Özcelik, 2010). Alternative assessment practices bring about three dimensions in

\footnotetext{
* Corresponding author: nidabuyuktokatli@gmail.com
} 
students' social literacy. First, the ideas and concepts in the minds of the students are exposed. Second, the development of students' analysis, evaluation, and synthesis skills are monitored. Third, students who complete alternative assessment activities improve their skills of generating broad-scale conclusions by linking new information with existing knowledge (Nelson \& Drake, 1997).

Aksu (2008) indicated that alternative assessment techniques have major advantages over traditional assessment techniques. Nevertheless, some research studies reveal that teachers do not prefer to use these techniques much. Some studies report that teachers use alternative techniques rarely because they don't have sufficient knowledge about these techniques (Akçadag, 2010; SağlamArslan, Avcl, \& İyibil, 2008; Yapalak, 2009; Yayla, 2011). The reason for teachers' being more apt to traditional assessment methods might be related to their lack of confidence in preparing, applying, and grading processes of alternative assessment techniques (Çalışkan \& Kaşıksız, 2010).

According to Sandford and Hsu (2013), the use of alternative assessment and evaluation does not bring a great solution for the problems of education. However, Orhan (2012) and Vurkaya(2010) studies revealed that alternative measurement and assessment techniques, whether separate or integrated with other approaches, have positive effects on student achievement, retention of knowledge, and attitudes towards the courses. In this study, teachers' practices of alternative assessment techniques will be investigated. This study is different from the previous studies related to the subject in the sense that it is conducted with a sample consisting of both science teachers and classroom teachers.

The aim of this study is to examine classroom teachers' and science teachers' practices of alternative assessment techniques and whether there is a difference in the frequencies of use of alternative assessment applications with regard to teachers' gender, branch, year of experience, and type of school they have graduated. Research questions are as follows:

1. How often classroom teachers and science teachers are using alternative assessment techniques?

2. Are there any differences in frequencies of teachers' use of alternative assessment techniques with respect to gender, branch, years of teaching experience, and type of school they graduated?

3. What are the difficulties that classroom teachers and science teachers encounter when using alternative assessment techniques?

4. What kind of applications classroom teachers and science teachers do after they complete the assessment process.

5. Which assessment approach are the teachers disposed to?

\section{Method}

\section{Research Design}

This study is a descriptive study with a general survey model, since a survey is conducted on the sample in order to have an overall judgment about the universe (Karasar, 2005). Some research questions were answered by using qualitative research techniques.

\section{Participants}

The sample of this study consists of 75 classroom teachers and 40 elementary school science teachers, majority of whom work in Aksaray $(\mathrm{N}=92)$ city centre schools. Twenty three of the teachers participated in the study from different provinces by means of online forms. The sample is easy to reach sample. This sampling method adds speed and practicality to a research (Yıldırım \& Şimşek, 2005).

\section{Instrument}

Data was collected by using a questionnaire developed by the researchers. When preparing questionnaire, a literature review was conducted and questionnaires previously used in other studies related to the subject were examined (Kanatlı, 2008; Orhan, 2007). The questionnaire consists of three 
sections. First section is related to personal characteristics of the teachers (gender, branch, years of teaching experience, faculty of graduation). Second section includes open ended questions related to the teachers' classroom applications of assessment. Third section includes a 4 point Likert type scale consisting of 17 items representing the alternative assessment techniques (performance task, drama, poster, structured grid, etc). Teachers are asked to indicate the frequency of use for each technique (1=never, $2=$ rarely, $3=$ sometimes, $4=$ very often).

Content validity of an instrument is related to extent to which it measures what it actually intended to measure (Balcl, 2004). Open-ended questions in the questionnaire were examined by a faculty member who is a specialist in the field and two teachers in order to determine whether questions are relevant for the purposes of the research and revised according to their suggestions. In addition, a pilot study with five teachers was performed to see whether the language and wording of the questions are clear and understandable. Responses of the teachers were examined by the researchers and the field specialist to determine whether the answers are compatible with the aims of the research and it was decided that the current wording of the questions are adequate.

\section{Data Analysis}

Data was analysed by using SPSS software. Descriptive statistics such as frequency and percentage were used to analyse the teachers' personal and professional information, and the frequency of use of alternative assessment techniques. Chi-square $\left(\chi^{2}\right)$ test was conducted to determine whether there are significant differences in frequencies of use of the alternative assessment tools with respect to gender, branch, years of teaching experience and type of graduated school. Responses to open-ended questions were analysed by conducting content analysis. To ensure the reliability of the research, questionnaire forms were analysed by each researcher independently. Furthermore, the responses to open-ended questions with the teachers' own handwriting has improved the reliability of the present research.

\section{Results}

This study determined in-service classroom and science teachers' frequency of use of alternative assessment techniques and their views about these techniques. Results of the study showed that the most frequently used techniques are worksheets (67\%) and performance assessments (62.6 \%). Less frequently used techniques are peer assessment (16.5\%), diagnostic tree (18.3\%), structured grid (19.1\%), and portfolio (29.6\%).

According to the results of the study, there is a significant difference in frequencies of use of alternative techniques between male and female teachers. According to the results, portfolio $\left(\chi^{2}=8.698\right.$, $p=.034)$, concept map $\left(\chi^{2}=11.825, p=.008\right)$, demonstration $\left(\chi^{2}=10.531, p=.015\right)$ and interview $\left(\chi^{2}=9.096\right.$, $p=.028)$ are used by female teachers more frequently than male teachers. Significant differences were found in frequencies of teachers' use of some alternative assessment techniques with regard to their teaching fields. Classroom teachers' used self-evaluation $\left(\chi^{2}=16.732, p=.001\right)$, poster $\left(\chi^{2}=10.629\right.$, $p=.014)$, semantic features analysis $\left(\chi^{2}=15.184, p=.002\right)$ and worksheets $\left(\chi^{2}=11.036, p=.012\right)$ more frequently than science and technology teachers. The results of this study showed that there were no differences in frequency of use of alternative techniques with regard to faculty of graduation. The results of the study also showed that the frequency of use of peer evaluation $\left(\chi^{2}=24.703, p=.000\right)$, selfevaluation $\left(\chi^{2}=15.862, p=.015\right)$, and diagnostic tree $\left(\chi^{2}=15.808, p=.015\right)$ differed by teachers' years of teaching experience.

Most of the teachers (59\%) participated in this study indicated that they had difficulty in practicing the alternative assessment techniques due to time constraints, crowded classrooms, concerns of objectivity, negative effects of parents, and insufficient knowledge about these techniques. Thirty three 
percent of the teachers, however, reported that they did not have difficulties in application of the alternative techniques.

In answering the question related to the applications done by the teachers when the assessment result shows that students have insufficient knowledge or misconceptions, majority of the teachers (74.8\%) reported that they re-teach the subject; some teachers stated that they perform another assessment by using different techniques (17.4\%); and a few teachers (4.3\%) reported that they try to make corrections immediately after the assessment.

A large part of the teachers (44\%) reported that they were more disposed to traditional techniques because they are used to traditional techniques, and they believe that they are more objective and time saving. On the other hand, a significant amount of teachers (33\%) reported that they are disposed to alternative techniques since they think alternative techniques take into consideration of individual differences more than the traditional techniques, provide more detailed information on students' learning, enable students to express themselves better, and that teachers should keep pace with innovations in the field of education.

\section{Discussion, Conclusion \& Implementation}

This study determined in-service classroom and science teachers' frequency of use of alternative assessment techniques and their views about these techniques. Results of the study showed that most frequently used techniques are worksheets and performance assessments. This finding is consistent with previous studies done in this subject. (Anıl \& Acar, 2008; Kanatlı, 2008; Kaya, Balay \& Göçen, 2012; Okur \& Azar, 2011; Şimşek, 2011, Yeşilyurt, 2012). The finding that one of the least preferred techniques is peer assessment is consistent with other studies (Adanalı \& Doğanay, 2010; Çelikkaya, Karakuş, \& Öztürk, 2010). Some studies also indicate that structured grids are less frequently used because teachers have not enough information about the technique. (Kanatlı, 2008; Karamustafaoğlu, Çağlak \& Meşeci, 2012; Kaya, et al., 2012; Okur, 2008; Okur \& Azar, 2011; Şimşek, 2011). Portfolio is also among the less preferred techniques in Turkey. However, as Sandford and Hsu (2013) found in their study that, although alternative techniques have not so big effect, portfolio use creates a significant impact on student learning.

The reason for less frequent use of structured grid and diagnostic tree is attributed to the lack of knowledge about these techniques by teachers in some studies. (Akçadağ, 2010; Sağlam-Arslan, et al., 2008; Yayla, 2011; Yapalak, 2009). However, as Karahan (2007) study suggested that these techniques have a positive effect on students' achievement. Some studies showed a need for organizing in-service seminars and workshops to introduce these techniques to teachers. (Anıl \& Acar, 2008; Çelikkaya et al., 2010; Çoruhlu, Nas, \& Çepni, 2009). Indeed, effective in service training's improving the effectiveness of assessment and evaluation process is among the findings of studies (Çoruhlu, et al., 2008; Şenel, 2008).

The result of the study showed that there is a significant difference in frequency of use of alternative techniques by gender of the teachers. According to the results, portfolio, concept map, demonstration and interview techniques are used by female teacher more frequently than male teachers. Some studies show that female teachers have also more positive views on these techniques. (Karamustafaoğlu et al., 2012; Okur \& Azar, 2011).

The results of this study showed that there is a significant difference in frequency of teachers' use of alternative assessment techniques according to their teaching fields in terms of self-evaluation, poster, semantic features analysis and worksheet. Classroom teachers use these techniques excluding posters more frequently than science and technology teachers. This might be because primary school textbooks and student workbooks contains many applications of these techniques and teachers can reach them 
easily. Besides, these techniques might not be suitable for assessing some topics of science in the upper elementary grades.

The result of this study showed that there were no differences in frequency of using alternative techniques in terms of faculty of graduation of the teachers. Some of the previous studies revealed the same result (Kaya, et al., 2012; Karamustafaoğlu, et al., 2012; Okur \& Azar, 2011). However, in one study by Kanatlı it was shown that the teachers graduated from faculties other than Faculty of Education have more positive views about using alternative techniques.

The results of the study also showed that the frequency of use of peer evaluation, self-evaluation, and diagnostic tree differed according to the teachers' professional experience. Kanatlı (2008) and Karamustafaoğlu et al. (2012) studies suggested that novice teachers' views on alternative techniques are more positive than more experienced teachers. On the other hand, some other studies showed that senior teachers' knowledge level on them and the frequency of using them were higher than the novice teachers. (Kaya, et al., 2012; Okur, 2008; Okur \& Azar, 2011). The present study, consistent with the later group, suggests that senior teachers' self-efficacy beliefs might be stronger than the novice teachers in general and in using new techniques.

Most of the teachers (\%59) participated in this study indicated that they had difficulty in practicing the alternative assessment techniques due to time constraints, crowded classrooms, concerns of objectivity, negative effects of parents, and insufficient knowledge on these techniques. Some previous studies support this finding. (Anıl \& Acar, 2008; Baki \& Birgin, 2002; Okur, 2008; Orhan, 2007; SağlamArslan, Devecioğlu-Kaymakçı, \& Aslan, 2009; Yeşilyurt, 2012). In other studies, teachers indicated that these new techniques are time consuming, and that it is difficult to use them in the limited class hours (Aksu, 2008). Another study by Ercan and Altun, revealed that teachers find these techniques hard to implement already and the classrooms being crowded make it harder to use (cited by Gömleksiz \& Bulut, 2007).

Some studies suggested that teachers are more disposed to traditional assessment techniques (Anıl \& Acar,2008; Çelikkaya, et al., 2010; Çoruhlu, et al., 2009; Kirman, 2008; Kocaarslan, 2012; Okur, 2008; Yeşilyurt, 2012). However, the present study showed that teachers partly moved away from traditional assessment techniques towards alternative techniques. 


\section{Fen Eğitiminde Alternatif Ölçme Değerlendirme Uygulamaları Nida BÜYÜKTOKATLI ${ }^{a^{*}}$, Şule BAYRAKTAR ${ }^{b}$}

${ }^{a}$ Milli Eğitim Bakanlığı, Bağı İlkokulu, Aksaray/Türkiye ${ }^{\mathrm{b}}$ Necmettin Erbakan Üniversitesi, Eğitim Fakültesi, Konya/Türkiye

\begin{tabular}{|c|c|}
\hline \multicolumn{2}{|c|}{ Makale Bilgisi } \\
\hline \multicolumn{2}{|c|}{ DOI: 10.14527/pegegog.2014.006 } \\
\hline \multicolumn{2}{|c|}{ Makale geçmişi: } \\
\hline Geliş & 13 Temmuz 2013 \\
\hline Düzeltme & 11 Kasım 2013 \\
\hline Kabul & 27 Ocak 2014 \\
\hline \multicolumn{2}{|c|}{$\begin{array}{l}\text { Anahtar kelimeler: } \\
\text { Fen Bilimleri dersi, } \\
\text { Ölçme ve değerlendirme, } \\
\text { Ölçme ve değerlendirme } \\
\text { teknikleri. }\end{array}$} \\
\hline
\end{tabular}

\begin{abstract}
Öz
$\mathrm{Bu}$ araştırma sınıf öğretmenleri ile fen bilimleri öğretmenlerinin alternatif ölçme değerlendirme tekniklerini hangi sıkıkta kullandıklarını ve alternatif teknikleri kullanma sıklıklarında cinsiyet, branş, kıdem ve mezun oldukları okul türü sıklıklarına göre bir farklılık bulunup bulunmadığını belirlemek amacıyla yapılmıştır. Çalışmada ayrıca öğretmenlerin alternatif ölçme ve değerlendirme teknikleri hakkındaki görüşleri ve ölçme değerlendirme sonunda yaptıkları geri bildirim uygulamalarına ilişkin bilgiler de toplanmıştır. Çalışma 2012- 2013 eğitim-öğretim yllında çoğunluğu Aksaray ili Merkez ilçe ilköğretim okullarından olmak üzere toplam 75 sınıf öğretmeni ile 40 fen bilimleri öğretmeni ile gerçekleștirilmiştir. Araştırmanın verileri araștırmacılar tarafından geliştirilen 3 açık uçlu soru ve 17 likert tipi sorudan oluşan anket formu ile toplanmışır. Gerçekleștirilen analiz sonuçlarına göre öğretmenlerin alternatif ölçme değerlendirme araçlarını kullanma sıklıklarının cinsiyete, branşa ve hizmet yılına bağlı olarak farklıık gösterdiği tespit edilmiştir. Bu bulgular doğrultusunda bazı önerilerde bulunulmuştur.
\end{abstract}

\section{Giriş}

Ölçme ve değerlendirme, eğitim ve öğretimin önemli bir parçasıdır. Eğitimde, programların istenilen başarıyı gösterip göstermediği, öğrencilerden beklenen bilgi, beceri ve tutumların gelişip gelişmediği, ölçme ve değerlendirme yoluyla tespit edilir. Ölçme ve değerlendirme ile eğitim ve öğretim sürecinin sürekli izlenmesi her aşamada ortaya çıkan sorunları tespit ve düzenleme imkânı verir (MEB, 2006).

Değerlendirme, öğretme ve öğretmenin etkililiğini belirlemek amacıyla yapılan, eğitimle ilgili verilerin toplanmasını ve yorumlanmasını içeren sistematik bir süreçtir. Değerlendirme bir yargılama işlemidir ve ölçme sonucunun bir ölçütle karşılaştırılmasına dayanır (MEB, 2005). Okul programlarının ayrılmaz bir parçasını oluşturan değerlendirme öğrencilerin eğitiminde çok önemli bir role sahiptir. Geçerliği ve güvenirliği yüksek ölçümlere dayalı olarak öğrenciler hakkında sağıklı kararlara ulaşabilmek iyi bir ölçme ve değerlendirme sürecini gerektirir. İyi bir ölçme değerlendirme sistemi öğrencinin neyi bildiğini gösteren, öğrenme sürecini planlamaya yardımcı olan, öğrencilerin nasıl daha iyi öğrenebileceği ve daha iyi yapabileceğini betimlemeye yardım eden ve öğrencinin öğrenme süreci hakkında bilgi sağlayan nitelikte olmalıdır. Değerlendirme bir süreç olarak ele alınmalı ve bu süreç içerisinde öğrencinin hem akademik başarısı hem de gelişimi sürekli izlenmelidir. Geleneksel olan anlayışta, öğretmene değerlendirme etkinliğinin tek belirleyicisi ve yürütücüsü rolü verilmektedir. Bu tür değerlendirme anlayışında öğrencinin bilgiyi öğrenirken nasıl bir yol izlediği, nasıl düşündüğü, nasıl analizler yaptığı ve bilgiyi nasıl yapılandırdığı ve diğer insanlarla nasıl iletişim kurduğu gözlenememektedir (Öncü, 2009).

Öğretmenler öğrencilerini başlıca iki amaçla değerlendirirler: (1) öğrencilerin öğrenmelerini izleme ve hem bireysel hem de tüm sınıflar için öğretimde gerekli değişiklikleri yapma ve (2) öğretimin bir dönemi sonunda öğrencilere not verme (Özçelik, 2010). Ölçme değerlendirme programın öğelerinden

*Yazar: nidabuyuktokatli@gmail.com 
öğrenmenin niteliğini belirleyen önemli bir unsur olduğuna göre nasıl uygulandığı önem arz etmektedir. Türk Eğitim Sistemi 2005-2006 öğretim yılı itibariyle yapılandırmacı öğrenme kuramına göre öğretim programları düzenlenerek değiştirilmiştir. Değişen program ile birlikte ölçme değerlendirme uygulamalarına da birtakım yenilikler getirilmiştir. Bu yenilikler ile ölçme ve değerlendirme yaklaşımında, geleneksel yaklaşımın unsurlarından derinliği olmadan çok sayıda kavram ve ilkeyi öğrenme, rutin problemleri çözebilme, ezber bilgi ve yazııı materyallerden bilgiyi aynen aktarmanın önemi azalmıştır. Ölçme ve değerlendirme etkinlikleriyle öğrencilerin üst düzey becerileri değerlendirilmeye çalışılmalıdır (MEB, 2006). Programlardaki bu değişimin hedeflerine bağlı olarak ölçme-değerlendirme yaklaşımlarının da farklılaşı̆ı̆ı görülmektedir. Buna göre, belirlenen hedeflere yönelik olarak geleneksel ölçme ve değerlendirme yaklaşımlarının yerini sürece dayalı alternatif ölçme ve değerlendirme yaklaşımları almıştır (EARGED, 2006; MEB, 2004).

Alternatif ölçme ve değerlendirme uygulamaları öğrencilerin sosyal okuryazarlıklarında en az üç boyut ortaya çıkarır. Birincisi, alternatif değerlendirme sonunda öğrencilerin zihinlerindeki kavramlar ve fikirler açığa çıkar. İkincisi, öğrencilerin analiz, değerlendirme ve sentez becerilerinin gelişimini gösterir. Üçüncüsü, alternatif değerlendirme aktivitelerini tamamlayan öğrenciler mevcut bilgileri ile yeni bilgiler arasında bağlantı kurarak ve geniş kapsamlı sonuçlar çıkarma becerilerini geliştirirler (Nelson ve Drake, 1997). Alternatif ölçme ve değerlendirme yaklaşımının geleneksel ölçme değerlendirme yaklaşımın yerini alması ile öğrenme öğretme sürecinin bir parçası olan, öğrenme öğretme ve planlamayı doğrudan etkileyen ve eğitim sisteminin temel öğelerinden biri olan değerlendirme, fen bilimleri eğitiminde farklı şekillerde kullanılabilir (MEB, 2005).

Tablo 1.

Fen ve Teknoloji Dersi Öğretim Programı'nda Değerlendirme Açısından Vurgular.

\begin{tabular}{ll}
\hline Daha Az Vurgu & Daha Çok Vurgu \\
\hline Geleneksel ölçme ve değerlendirme yöntemleri & Alternatif ölçme ve değerlendirme yöntemleri \\
Öğretme ve öğrenmeden bağımsız değerlendirme & $\begin{array}{l}\text { Öğretmenin ve öğrenme bir parçası olan } \\
\text { değerlendirme }\end{array}$ \\
Ezbere, kolay öğrenilen bilgileri değerlendirme & $\begin{array}{l}\text { Anlamlı ve derin öğrenilebilen bilgileri } \\
\text { değerlendirme }\end{array}$ \\
Birbirinden bağımsız parçalı bilgileri değerlendirme & $\begin{array}{l}\text { Birbirine bağlı, iyi yapılanmış bir bilgi ağını } \\
\text { değerlendirme }\end{array}$ \\
Bilimsel bilgiyi değerlendirme & $\begin{array}{l}\text { Bilimsel anlamayı ve bilimsel mantığı } \\
\text { değerlendirme }\end{array}$ \\
Öğrencinin bilmediğini öğrenmek için & $\begin{array}{l}\text { Öğrencinin ne anladığı öğrenmek amacı ile } \\
\text { değerlendirme }\end{array}$ \\
değerlendirme & Dönem boyunca devam eden değerlendirme \\
Dönem sonu değerlendirme etkinlikleri & etkinlikleri \\
Sadece öğretmenin değerlendirmesi & Öğretmenle beraber grup değerlendirmesi ve \\
& kendi kendini değerlendirme \\
\hline
\end{tabular}

(MEB, 2005).

Türk Eğitim Sistemindeki değişikliklerle birlikte uygulanmaya başlayan alternatif ölçme değerlendirmeye geçiş sürecinde bu konu ile ilgili birçok araştırma yapılmıştır. Alternatif ölçme değerlendirme tekniklerinin kullanımına ilişkin literatür incelendiğinde en sık kullanılan alternatif ölçme tekniğinin performans değerlendirme olduğu görülmüştür (Adanalı ve Doğanay, 2010; Anıl ve Acar, 2008; Kanatlı, 2008; Karamustafaoğlu, Çağlak, ve Meşeci, 2012; Kaya, Balay, ve Göçen, 2012;Okur ve Azar, 2011; Yeşilyurt, 2012; Şimşek, 2011). En az kullanılan alternatif ölçme teknikleri olarak yapılandırılmış grid ve tanılayıcı dallanmış ağaç olduğu tespit edilmiştir (Kanatlı, 2008; Karamustafaoğlu, vd., 2012; Kaya, vd., 2012; Okur, 2008; Okur ve Azar, 2011; Sağlam, vd., 2009; Şimşek, 2011). 
Aksu (2008), araştırmasının sonuçlarının, alternatif ölçme ve değerlendirme tekniklerinin geleneksel ölçme değerlendirme tekniklerinden çok farklı olduğunu gösterdiğini belirtmektedir. Bununla birlikte bazı araştırmalar geleneksel ölçme değerlendirme tekniklerinin kullanımından vazgeçilmediğinden bahsetmektedir. Ölçme ve değerlendirme çalışmalarında öğretmenlerin en çok geleneksel ölçme ve değerlendirme tekniklerini tercih ettikleri, alternatif ölçme ve değerlendirme tekniklerinin bazılarının öğretmenler tarafından iyi bilindiği; fakat birçoğu hakkında öğretmenlerin bilgi düzeyinin oldukça az olduğu sonucuna ulaşılmıştır (Okur, 2008). Alternatif ölçme değerlendirme tekniklerinin az kullanılmasına ilişkin öğretmenlerin bu teknikler hakkında bilgi eksiklikleri bulunduğu, öz yeterlikleri olmadığı farklı araştırmalarda desteklenmektedir (Akçadağ, 2010; Sağlam-Arslan, Avcı, ve İyibil, 2008; Yapalak, 2009; Yayla, 2011). Öğretmenlerin bildikleri teknikleri kullanmada kararlılık gösterdikleri, bildiklerini yeni karşılaştıkları durumlara uyarlamaya çalıştıkları düşünülebilir (Çepni ve Çoruhlu 2010).

Öğretmenler, 2005 yılından bu yana uygulanmakta olan alternatif ölçme ve değerlendirme tekniklerini gerektiği gibi uygulama yönünde aradan geçen süreye rağmen halen sorun yaşamaktadırlar. Öğretmenlerin geleneksel yönteme yaygın olarak başvurmalarının nedeni bu yöntemi hazırlamada, kullanmada ve değerlendirmede kendilerini daha yeterli hissetmelerinden kaynaklanabilir (Çalışkan ve Kaşıksız, 2010). Bu nedenle, yapılandırmacı öğrenme kuramı temelli programlarla uygulanmaya başlayan alternatif ölçme ve değerlendirme tekniklerinin öğretmenler tarafından ne ölçüde bilindiği, uygulandığı ve bu tekniklere ilişkin eğitim intiyacının ne düzeyde olduğu somut araştırma bulguları ile desteklenmesi gerekmektedir (Kaya, vd., 2012).

Literatür incelendiğinde alternatif ölçme teknikleri ile ilgili bilgi eksikliklerinin hizmet içi eğitimlerin yetersizliğinden ve verimsiz bir şekilde uygulanmasından kaynaklandığı tespit edilmiştir (Anıl ve Acar, 2008; Çelikkaya, Karakuş, ve Öztürk, 2010; Çoruhlu, Nas ve Çepni, 2009). Öte yandan Şenel (2008) alternatif ölçme değerlendirme ile ilgili yaptığı araştırmada hizmet içi eğitim kursunun öğretmenlerin alternatif ölçme-değerlendirme tekniklerini derslerinde kullanmaları konusunda olumlu etkide bulunduğu ve öğretmenlerin bu teknikleri sınıflarında istekli olarak kullandıkları sonucuna varmıştır.

Sandford ve Hsu (2013)'e göre alternatif değerlendirmenin kullanımı değerlendiriciler ile değerlendirme disiplininde büyük bir çözüm getirmeyecektir. Öte yandan Orhan (2012)'ye göre alternatif ölçme ve değerlendirme teknikleri ister ayrı ayrı, ister karma olarak ele alınsın araştırma bulgularına göre hemen hemen hepsinde alternatif ölçme ve değerlendirme tekniklerinin öğrenci başarısını, bilgilerin kalıcılığını ve derse yönelik tutum ve görüşlerini olumlu yönde artırmaktadır. Vurkaya (2010)'a göre alternatif süreç değerlendirme etkinliklerinin öğrenci başarııına pozitif bir etki yaptığı konusundaki düşünceleri güçlendirmektedir. Bu araştırmada öğrenci başarısını arttırdığı varsayılan ve yapılandırmacı öğrenme kuramına uygun olan alternatif ölçme değerlendirme tekniklerinin öğretmenler tarafından uygulanma düzeyi araştırılacaktır. Bu çalışma hem sınıf öğretmeni hem de fen bilimleri öğretmenleri ile yapılması dolayısıyla alanda yapılan önceki çalışmalardan farklıdır.

Bu çalışmanın amacı sınıf öğretmeni ve fen bilimleri öğretmenlerinin alternatif ölçme değerlendirme tekniklerini kullanımlarının cinsiyete, branşlarına, kıdemlerine ve mezun oldukları okul türüne göre değişimini ve alternatif ölçme tekniklerini uygulama durumları incelemektir. Bu amaç doğrultusunda aşağıdaki alt problemlere cevap aranmıştır:

1. Sınıf öğretmeni ve fen bilimleri öğretmenleri alternatif ölçme değerlendirme tekniklerini ne sıklıkta kullanmaktadırlar?

2. Sınıf öğretmeni ve fen $v$ bilimleri öğretmenlerinin alternatif ölçme değerlendirme tekniklerini kullanımları cinsiyete, branşlarına, kıdemlerine ve mezun oldukları okul türüne göre değişmekte midir?

3. Sınıf öğretmeni ve fen bilimleri öğretmenlerinin alternatif ölçme değerlendirme tekniklerini kullanırken karşılaştıkları güçlükler nelerdir?

4. Sınıf öğretmeni ve fen bilimleri öğretmenleri ölçme değerlendirme sonuçlarına göre ne tür uygulamalar yapmaktadırlar? 
5. Sınıf öğretmeni ve Fen bilimleri öğretmenlerinin ölçme değerlendirme yöntemlerine eğilimi ne yöndedir?

\section{Yöntem}

\section{Araştırma Modeli}

Araştırma genel tarama türünde betimsel bir çalışmadır. Genel tarama modelleri, çok sayıda elemandan oluşan bir evrende, evren hakkında genel bir yargıya varmak amacı ile evrenin tümü ya da ondan alınacak bir grup üzerinde yapılan düzenlemelerdir (Karasar, 2005: 79). Ayrıca araştırmanın 3., 4. ve 5. alt problemlerinde nitel çözümleme teknikleri kullanılmıştır.

\section{Katılımcılar}

Araştırma çoğunluğu Aksaray ili Merkez ilçe ilköğretim okullarından olmak üzere toplam 75 sınıf öğretmeni ile 40 Fen bilimleri öğretmeni ile gerçekleştirilmiştir. Örneklem kolay ulaşılabilir durum örneklemesidir. Bu örnekleme yöntemi araştırmaya hız ve pratiklik kazandırır (Yıldırım ve Şimşek, 2005). Örneklemde farklı illerden öğretmenlerin olması online veri toplama yapılmasından kaynaklanmaktadır. Öğretmenlerin çalıştıkları illere göre dağılımı aşağıda Tablo 2'de sunulmuştur.

Tablo 2.

Öğretmenlerin Çalıştıkları Şehirlere Göre Dağılımı.

\begin{tabular}{|c|c|c|c|c|c|c|c|c|c|c|c|c|c|c|}
\hline & \multicolumn{2}{|c|}{ Aksaray } & \multicolumn{2}{|c|}{ İstanbul } & \multicolumn{2}{|c|}{ Konya } & \multicolumn{2}{|c|}{ Sivas } & \multicolumn{2}{|c|}{ Bilecik } & \multicolumn{2}{|c|}{ İzmir } & \multicolumn{2}{|c|}{ Toplam } \\
\hline & $f$ & $\%$ & $f$ & $\%$ & $f$ & $\%$ & $f$ & $\%$ & $f$ & $\%$ & $\mathrm{~F}$ & $\%$ & $f$ & $\%$ \\
\hline $\begin{array}{l}\text { Sınıf } \\
\text { Öğretmeni }\end{array}$ & 61 & 66.3 & 2 & 33.3 & 7 & 63.6 & 1 & 50.0 & 1 & 100 & 3 & 100 & 75 & 65.2 \\
\hline $\begin{array}{l}\text { Fen Bilimleri } \\
\text { Öğretmeni }\end{array}$ & 31 & 33.7 & 4 & 66.7 & 4 & 36.4 & 1 & 50 & 0 & 0 & 0 & 0 & 40 & 34.8 \\
\hline Toplam & 92 & 80 & 6 & 5.2 & 11 & 9.6 & 2 & 1.7 & 1 & 0.9 & 3 & 2.6 & 115 & 100 \\
\hline
\end{tabular}

\section{Veri Toplama Aracı}

Araştırmada veri toplama aracı olarak araştırmacılar tarafından geliştirilen anket formu kullanılmıştır. Anket oluşturulurken öncelikle literatür taraması yapılarak daha önce bu amaçla hazırlanmış olan başka anketler incelenmiştir (Kanatlı, 2008; Orhan, 2007). Anket, 3 bölümden oluşmaktadır. Birinci bölümde kişisel bilgiler (cinsiyet, branş...), II. bölümde 3 adet açık uçlu soru (Ölçme değerlendirme sonunda öğrencilerde eksik ya da hatalı bulduğunuz konularla ilgili olarak geri dönüt sağlamada ne gibi uygulamalar yapıyorsunuz? Açıklayınız.), III. bölümde ise 17 adet alternatif ölçme değerlendirme tekniğini (performans, drama, poster, yapılandırılmış grid, vb.) kullanma durumlarına yönelik "Sıklıkla", "Arada sırada", "Nadiren" ve "Hiçbir zaman" seçeneklerinden oluşan dörtlü Likert tipi maddelere yer verilmiştir.

Balcı (2004)' e göre bir ölçme aracının içerik-muhtevasını beklenen davranışları ne derecede ölçtüğünün tayin edilmesidir. Anket formundaki açık uçlu soruların amaca uygunluğunu denetlemek için, anket alan uzmanı bir öğretim üyesi ve iki öğretmen tarafından incelenerek soru ifadeleri onlar tarafından gelen öneriler doğrultusunda yeniden düzenlenmiştir. Ayrıca beş öğretmene pilot çalışma yapılarak soruların dil ve anlatımının açık ve anlaşılır olup olmadığı, verilen yanıtların sorulardan amaçlananları yansıtıp yansıtmadığı araştırmacılarla alan uzmanı tarafından incelenerek soru ifadelerinin geçerli olduğuna karar verilmiştir. 


\section{Verilerin Toplanması}

Araştırma kapsamında geliştirilen anket formu araştırmacı tarafından okullardaki öğretmenlere dağıtılmıştır. Öğretmenlerin anketi tamamlamaları ardından anketler geri toplanmıştır. Araştırmacı elektronik posta yoluyla da veri toplamıştır. Toplamda 115 anket formu ile elde edilen verilerin çoğunluğu 92 (\% 80) araştırmacı tarafından okullardaki öğretmenlere dağıtılmıştır. Verilerin 23 (\% 20) kadarı ise elektronik posta yoluyla elde edilmiştir.

\section{Verilerin Analizi}

Elde edilen veriler bilgisayarda SPSS programı ile öğretmenlere ait kişisel ve mesleki bilgiler, ölçme ve değerlendirme araçlarını kullanma sıklıkları frekans (f) ve yüzde (\%) dağılımı olarak belirtilmiştir. Alternatif ölçme ve değerlendirme araçlarını kullanma sıklığı ile cinsiyet, branş, mesleki kıdem ve mezun olunan okul türü değişkenleri arasında ilişki olup olmadığını sınamak amacıyla iki değişkenli Ki Kare $\left(\chi^{2}\right)$ testinden yararlanılmıştır. Açık uçlu sorulara verilen cevaplar araştırmacılar tarafından okunarak içerik analizi yapılmıştır. İçerik analizinde temelde yapılan işlem, birbirine benzeyen verileri belirli kavramlar ve temalar çerçevesinde bir araya getirmek ve bunları okuyucunun anlayabileceği bir biçimde düzenleyerek yorumlamaktır (Yıldırım ve Şimşek, 2005). Öğretmenlerin açık uçlu sorulara verdikleri cevaplar araştırmacılar tarafından kodlanarak analiz edilmiştir. Araştırmanın güvenilirliğini sağlamak için anketler her bir araştırmacı tarafından ayrı ayrı bağımsız olarak incelenmiştir. Bununla beraber açık uçlu sorulara verilen cevaplar öğretmenlerin kendi el yazılarıyla sunularak araştırmanın güvenirliği arttırılmıştır.

\section{Bulgular}

\section{Alternatif Ölçme Değerlendirme Tekniklerinin Kullanımına ilişkin Bulgular}

\section{Kullanma sıklığına ilişkin bulgular}

Araştırma kapsamında elde edilen veriler analiz edilerek öğretmenlerin alternatif teknikleri ne sıklıkta kullandıkları aşağıda Tablo 3'de sunulmuştur.

Tablo 3.

Alternatif Ölçme Değerlendirme Teknikleri Kullanma Sıklığı.

\begin{tabular}{|c|c|c|c|c|c|c|c|c|c|c|}
\hline \multirow[t]{2}{*}{ Alternatif Teknikler } & \multicolumn{2}{|c|}{ Sıklıkla } & \multicolumn{2}{|c|}{$\begin{array}{l}\text { Arada } \\
\text { Sırada }\end{array}$} & \multicolumn{2}{|c|}{ Nadiren } & \multicolumn{2}{|c|}{$\begin{array}{l}\text { Hiçbir } \\
\text { zaman }\end{array}$} & \multicolumn{2}{|c|}{ Toplam } \\
\hline & f & $\%$ & f & $\%$ & f & $\%$ & f & $\%$ & $f$ & $\%$ \\
\hline Proje & 30 & 26.1 & 58 & 50.4 & 23 & 20.0 & 4 & 3.5 & 115 & 100 \\
\hline Performans & 72 & 62.6 & 31 & 27.0 & 10 & 8.7 & 2 & 1.7 & 115 & 100 \\
\hline Gözlem formu(rubrik) & 25 & 21.7 & 50 & 43.5 & 29 & 25.2 & 11 & 9.6 & 115 & 100 \\
\hline Portfolyo(ürün dosyası) & 34 & 29.6 & 38 & 33.0 & 23 & 20.0 & 20 & 17.4 & 115 & 100 \\
\hline Akran değerlendirmesi & 19 & 16.5 & 32 & 27.8 & 38 & 33.0 & 26 & 22.6 & 115 & 100 \\
\hline Öz değerlendirme & 39 & 33.9 & 30 & 26.1 & 29 & 25.2 & 17 & 14.8 & 115 & 100 \\
\hline Kavram haritası & 57 & 49.6 & 35 & 30.4 & 14 & 12.2 & 9 & 7.8 & 115 & 100 \\
\hline Tanılayıcı dallanmış ağaç & 21 & 18.3 & 48 & 41.7 & 27 & 23.5 & 19 & 16.5 & 115 & 100 \\
\hline Yapılandırılmış grid & 22 & 19.1 & 41 & 35.7 & 27 & 23.5 & 25 & 21.7 & 115 & 100 \\
\hline Poster & 50 & 43.5 & 38 & 33.0 & 25 & 21.7 & 2 & 1.7 & 115 & 100 \\
\hline Gösteri & 46 & 40.0 & 38 & 33.0 & 23 & 20.0 & 8 & 7.0 & 115 & 100 \\
\hline Drama & 41 & 35.7 & 39 & 33.9 & 24 & 20.9 & 11 & 9.6 & 115 & 100 \\
\hline Kelime ilişkilendirme & 58 & 50.4 & 37 & 32.2 & 14 & 12.2 & 6 & 5.2 & 115 & 100 \\
\hline Anlam çözümleme tablosu & 38 & 33.0 & 40 & 34.8 & 23 & 20.0 & 14 & 12.2 & 115 & 100 \\
\hline Çalışma yaprağı & 77 & 67.0 & 23 & 20.0 & 10 & 8.7 & 5 & 4.3 & 115 & 100 \\
\hline Bulmaca & 68 & 59.1 & 35 & 30.4 & 10 & 8.7 & 2 & 1.7 & 115 & 100 \\
\hline Görüşme (mülakat) & 43 & 37.4 & 36 & 31.3 & 25 & 21.7 & 11 & 9.6 & 115 & 100 \\
\hline
\end{tabular}


Tablo 3'de öğretmenlerin alternatif ölçme değerlendirme tekniklerini kullanma sıklıkları incelendiğinde en sık kullanılan tekniklerin çalışma yaprağı ve performans değerlendirme, en az kullanılan tekniklerin ise akran değerlendirmesi, yapılandırılmış grid, portfolyo ve tanılayıcı dallanmış ağaç olduğu tespit edilmiştir.

\section{Alternatif Tekniklerin Kullanımının Cinsiyete, Branşa, Mezun Oldukları Okul Türüne ve Hizmet Yılına Göre Değişimi}

\section{Cinsiyet değişkenine göre alternatif ölçme ve değerlendirme araçlarını kullanma sıklığı}

Araştırmada belirlenen alt problemlerden öğretmenlerin cinsiyeti ile alternatif ölçme değerlendirme teknikleri kullanma sıklığı arasında ilişki olup olmadığı sorusuna ait bulgular aşağıda sunulmuştur. Cinsiyet değişkenine göre portfolyo, kavram haritası, gösteri ve görüşme tekniklerinin kullanım sıklığı bakımından Ki Kare $\left(\chi^{2}\right)$ testinde istatistiksel açıdan .05 düzeyinde anlamlı bir ilişki olduğundan sadece bu dört tekniğe ilişkin bulgular sunulmuştur.

Tablo 4.

Portfolyo (Ürün Dosyası) Kullanma Sıklığı ve Cinsiyet Değişkeni Arasındaki Illişki.

\begin{tabular}{lccccccccccc}
\hline Cinsiyet & \multicolumn{2}{c}{ Sıklıkla } & \multicolumn{2}{c}{ Arada } & \multicolumn{2}{c}{ Nadiren } & \multicolumn{2}{c}{ Hiçbir } & \multicolumn{2}{c}{ Toplam } \\
& & f & \% & f & \% & f & \% & f & \% & f & \% \\
\hline Erkek & 12 & 19.4 & 22 & 35.5 & 17 & 27.4 & 11 & 17.7 & 62 & 100 \\
Kadın & 22 & 41.5 & 16 & 30.2 & 6 & 11.3 & 9 & 17.0 & 53 & 100 \\
Toplam & 34 & 29.6 & 38 & 33.0 & 23 & 20.0 & 20 & 17.4 & 115 & 100 \\
$\chi^{2}(3)=8.698$ & & & & & & & & & $\mathrm{p}=.034$ \\
\hline
\end{tabular}

Tablo 4'de görüldüğü üzere öğretmenlerin cinsiyeti ile alternatif teknikleri kullanma sıklığı bakımından Ki Kare $\left(\chi^{2}\right)$ testinde istatistiksel açıdan .05 düzeyinde anlamlı bir ilişki bulunduğu görülmektedir $(p<.05)$. Bu bulgulara dayanılarak cinsiyetin, portfolyo kullanımında anlamlı bir değişken olduğu söylenebilir.

Tablo 5.

Kavram Haritası Kullanma Sıklığı ve Cinsiyet Değişkeni Arasındaki ilişki.

\begin{tabular}{lccccccccccc}
\hline Cinsiyet & \multicolumn{2}{c}{ Sıklıkla } & \multicolumn{2}{c}{$\begin{array}{c}\text { Arada } \\
\text { Sırada }\end{array}$} & \multicolumn{2}{c}{ Nadiren } & \multicolumn{2}{c}{ Hiçbir } & \multicolumn{2}{c}{ Toplam } \\
& $\mathbf{f}$ & $\mathbf{\%}$ & $\mathbf{f}$ & $\mathbf{\%}$ & $\mathbf{f}$ & $\mathbf{\%}$ & $\mathbf{f}$ & $\mathbf{\%}$ & $\mathbf{f}$ & $\%$ \\
\hline Erkek & 22 & 35.5 & 25 & 40.3 & 8 & 12.9 & 7 & 11.3 & 62 & 100 \\
Kadın & 35 & 66.0 & 10 & 18.9 & 6 & 11.3 & 2 & 3.8 & 53 & 100 \\
Toplam & 57 & 49.6 & 35 & 20.4 & 14 & 12.2 & 9 & 7.8 & 115 & 100 \\
$\chi^{2}(3)=11.825$ & & & & & & & & & $\mathrm{p}=.008$ \\
\hline
\end{tabular}

Tablo 5'de görüldüğü üzere öğretmenlerinin kavram haritası kullanma sıklığı ile cinsiyet değişkeni arasında yapılan Ki Kare $\left(\chi^{2}\right)$ testinde istatistiksel açıdan .05 düzeyinde anlamlı bir ilişki bulunduğu görülmektedir $(p<.05)$. Bu bulgulara dayanılarak cinsiyetin kavram haritası kullanımında anlamlı bir değişken olduğu söylenebilir. 
Tablo 6.

Gösteri Kullanma Sıklığı ve Cinsiyet Değişkeni Arasındaki Iliş̧ki.

\begin{tabular}{lccccccccccc}
\hline Cinsiyet & \multicolumn{2}{c}{ Sıklıkla } & \multicolumn{2}{c}{ Arada } & \multicolumn{3}{c}{ Nadirada } & \multicolumn{2}{c}{ Hiçbir } & \multicolumn{2}{c}{ Toplam } \\
& $\mathbf{f}$ & $\mathbf{\%}$ & $\mathbf{f}$ & $\mathbf{\%}$ & $\mathbf{f}$ & $\mathbf{\%}$ & $\mathbf{f}$ & $\%$ & $\mathbf{f}$ & $\%$ \\
\hline Erkek & 20 & 32.3 & 20 & 32.3 & 19 & 30.6 & 3 & 4.8 & 62 & 100 \\
Kadın & 26 & 49.1 & 18 & 34.0 & 4 & 7.5 & 5 & 9.4 & 53 & 100 \\
Toplam & 46 & 40.0 & 38 & 33.0 & 23 & 20.0 & 8 & 7.0 & 115 & 100 \\
$\chi^{2}(3)=10.531$ & & & & & & & & & $\mathrm{p}=.015$ \\
\hline
\end{tabular}

Tablo 6'da görüldüğü üzere öğretmenlerinin gösteri tekniğini kullanma sıklığı ile cinsiyet değişkeni arasında yapılan Ki Kare $\left(\chi^{2}\right)$ testinde istatistiksel açıdan .05 düzeyinde anlamlı bir ilişki bulunduğu görülmektedir $(p<.05)$. Bu bulgulara dayanılarak cinsiyetin gösteri tekniği kullanımında anlamlı bir değişken olduğu söylenebilir.

Tablo 7.

Görüşme Kullanma Sıklığı ve Cinsiyet Değişkeni Arasındaki ilişski.

\begin{tabular}{lccccccccccc}
\hline Cinsiyet & \multicolumn{2}{c}{ Sıklıkla } & \multicolumn{2}{c}{ Arada } & \multicolumn{3}{c}{ Sadirada } & \multicolumn{2}{c}{ Hiçbir } & \multicolumn{2}{c}{ Toplam } \\
& f & $\%$ & $\mathbf{f}$ & $\%$ & $\mathbf{f}$ & $\%$ & $\mathbf{f}$ & $\%$ & $\mathbf{f}$ & $\%$ \\
\hline Erkek & 20 & 32.3 & 16 & 25.8 & 20 & 32.3 & 6 & 9.7 & 62 & 100 \\
Kadın & 23 & 43.4 & 20 & 37.7 & 5 & 9.4 & 5 & 9.4 & 53 & 100 \\
Toplam & 43 & 37.4 & 36 & 31.3 & 25 & 21.7 & 11 & 9.6 & 115 & 100 \\
$\chi^{2}(3)=9.096$ & & & & & & & & & $\mathrm{p}=.028$ \\
\hline
\end{tabular}

Tablo 7'de görüldüğü üzere öğretmenlerinin görüşme tekniğini kullanma sıklığı ile cinsiyet değişkeni arasında yapılan Ki Kare $\left(\chi^{2}\right)$ testinde istatistiksel açıdan .05 düzeyinde anlamlı bir ilişki bulunduğu görülmektedir( $p<$.05). Bu bulgulara dayanılarak cinsiyetin görüşme tekniği kullanımında anlamlı bir değişken olduğu söylenebilir.

\section{Branş değişkenine göre alternatif ölçme ve değerlendirme araçlarını kullanma sıklığı}

Araştırmada belirlenen alt problemlerden öğretmenlerin branşı ile alternatif ölçme değerlendirme teknikleri kullanma sıklığı arasında ilişki olup olmadığı sorusuna ait bulgular aşağıda sunulmuştur. Branş değişkenine göre gözlem formu, portfolyo, akran değerlendirmesi, öz değerlendirme, poster, anlam çözümleme tablosu ve çalışma yaprağı tekniklerinin kullanım sıklığı bakımından Ki Kare $\left(\chi^{2}\right)$ testinde istatistiksel açıdan 05 düzeyinde anlamlı bir ilişki olduğundan sadece bu yedi tekniğe ilişkin bulgular sunulmuştur.

Tablo 8.

Gözlem Formu (Rubrik) Kullanma Sıklığı ve Branş Değişkeni Arasındaki iliş̧ki.

\begin{tabular}{|c|c|c|c|c|c|c|c|c|c|c|}
\hline \multirow[t]{2}{*}{ Branş } & \multicolumn{2}{|c|}{ Sıklıkla } & \multicolumn{2}{|c|}{$\begin{array}{l}\text { Arada } \\
\text { Sirada }\end{array}$} & \multicolumn{2}{|c|}{ Nadiren } & \multicolumn{2}{|c|}{$\begin{array}{l}\text { Hiçbir } \\
\text { Zaman }\end{array}$} & \multicolumn{2}{|c|}{ Toplam } \\
\hline & $f$ & $\%$ & $f$ & $\%$ & f & $\%$ & $f$ & $\%$ & $f$ & $\%$ \\
\hline Sınıf Öğretmeni & 18 & 24.0 & 39 & 52.0 & 14 & 18.7 & 4 & 5.3 & 75 & 100 \\
\hline Fen Bilimleri Öğretmeni & 7 & 17.5 & 11 & 27.5 & 15 & 37.5 & 7 & 17.5 & 40 & 100 \\
\hline Toplam & 25 & 21.7 & 50 & 43.5 & 29 & 25.2 & 11 & 9.6 & 115 & 100 \\
\hline$\chi^{2}(3)=11.815$ & & & & & & & & & \multicolumn{2}{|c|}{$p=.008$} \\
\hline
\end{tabular}


Tablo 8 'de görüldüğü üzere öğretmenlerinin gözlem formu tekniğini kullanma sıklığı ile branş değişkeni arasında yapılan Ki Kare $\left(\chi^{2}\right)$ testinde istatistiksel açıdan .05 düzeyinde anlamlı bir ilişki bulunduğu görülmektedir(p< .05). Bu bulgulara dayanılarak branşın gözlem formu tekniği kullanımında anlamlı bir değişken olduğu söylenebilir.

Tablo 9.

Portfolyo Kullanma Sıklığı ve Branş Değişkeni Arasındaki Ilişki.

\begin{tabular}{lccccccccccc}
\hline Branş & \multicolumn{2}{c}{ Sıklıkla } & \multicolumn{2}{c}{ Arada } & \multicolumn{3}{c}{ Sadiren } & \multicolumn{2}{c}{ Hiçbir } & \multicolumn{2}{c}{ Toplam } \\
& $\mathbf{f}$ & $\mathbf{\%}$ & $\mathbf{f}$ & $\mathbf{\%}$ & $\mathbf{f}$ & $\mathbf{\%}$ & $\mathbf{f}$ & $\mathbf{\%}$ & $\mathbf{f}$ & $\%$ \\
\hline Sınıf Öğretmeni & 27 & 36.0 & 24 & 32.0 & 16 & 21.3 & 8 & 10.7 & 75 & 100 \\
Fen Bilimleri Öğretmeni & 7 & 17.5 & 14 & 35.0 & 7 & 17.5 & 12 & 30.0 & 40 & 100 \\
Toplam & 34 & 29.6 & 38 & 33.0 & 23 & 20.0 & 20 & 17.4 & 115 & 100 \\
$\chi^{2}(3)=8.889$ & & & & & & & & & $\mathrm{p}=.031$ \\
\hline
\end{tabular}

Tablo 9'da görüldüğü üzere öğretmenlerinin portfolyo tekniğini kullanma sıklığı ile branş değişkeni arasında yapılan Ki Kare $\left(\chi^{2}\right)$ testinde istatistiksel açıdan .05 düzeyinde anlamlı bir ilişki bulunduğu görülmektedir( $p<.05)$. Bu bulgulara dayanılarak branşın, portfolyo tekniği kullanımında anlamlı bir değişken olduğu söylenebilir.

Tablo 10.

Akran Değerlendirmesi Kullanma Sıklığı ve Branş Değişkeni Arasındaki ilişki.

\begin{tabular}{|c|c|c|c|c|c|c|c|c|c|c|}
\hline \multirow[t]{2}{*}{ Branş } & \multicolumn{2}{|c|}{ Sıklıkla } & \multicolumn{2}{|c|}{$\begin{array}{l}\text { Arada } \\
\text { Sırada }\end{array}$} & \multicolumn{2}{|c|}{ Nadiren } & \multicolumn{2}{|c|}{$\begin{array}{l}\text { Hiçbir } \\
\text { Zaman }\end{array}$} & \multicolumn{2}{|c|}{ Toplam } \\
\hline & f & $\%$ & $f$ & $\%$ & f & $\%$ & f & $\%$ & f & $\%$ \\
\hline Sınıf Öğretmeni & 15 & 20.0 & 25 & 33.3 & 25 & 33.3 & 10 & 13.3 & 75 & 100 \\
\hline Fen Bilimleri Öğretmeni & 4 & 10.0 & 7 & 17.5 & 13 & 32.5 & 16 & 40.0 & 40 & 100 \\
\hline Toplam & 19 & 16.5 & 32 & 27.8 & 38 & 33.0 & 26 & 22.6 & 115 & 100 \\
\hline$\chi^{2}(3)=12.140$ & & & & & & & & & \multicolumn{2}{|c|}{$p=.007$} \\
\hline
\end{tabular}

Tablo 10'da görüldüğü üzere öğretmenlerinin akran değerlendirmesi tekniğini kullanma sıklığı ile branş değişkeni arasında yapılan Ki Kare $\left(\chi^{2}\right)$ testinde istatistiksel açıdan .05 düzeyinde anlamlı bir ilişki bulunduğu görülmektedir( $p<.05)$. Bu bulgulara dayanılarak branşın, akran değerlendirmesi tekniği kullanımında anlamlı bir değişken olduğu söylenebilir.

Tablo 11.

Öz Değerlendirme Kullanma Sıklığı ve Branş Değişkeni Arasındaki Ilişki.

\begin{tabular}{lccccccccccc}
\hline Branş & \multicolumn{2}{c}{ Sıklıkla } & \multicolumn{2}{c}{ Arada } & \multicolumn{3}{c}{ Sadirada } & \multicolumn{2}{c}{ Hiçbir } & \multicolumn{2}{c}{ Toplam } \\
& f & \% & f & \% & f & \% & f & \% & f & $\%$ \\
\hline Sınıf Öğretmeni & 31 & 41.3 & 20 & 26.7 & 20 & 26.7 & 4 & 5.3 & 75 & 100 \\
Fen Bilimleri Öğretmeni & 8 & 20.0 & 10 & 25.0 & 9 & 22.5 & 13 & 32.5 & 40 & 100 \\
Toplam & 39 & 33.9 & 30 & 26.1 & 29 & 25.2 & 17 & 14.8 & 115 & 100 \\
$\chi^{2}(3)=16.732$ & & & & & & & & & $\mathrm{p}=.001$ \\
\hline
\end{tabular}

Tablo 11'de görüldüğü üzere öğretmenlerinin öz değerlendirme tekniğini kullanma sıklığı ile branş değişkeni arasında yapılan Ki Kare $\left(\chi^{2}\right)$ testinde istatistiksel açıdan 05 düzeyinde anlamlı bir ilişki bulunduğu görülmektedir( $p<.05)$. Bu bulgulara dayanılarak branşın, öz değerlendirme tekniği kullanımında anlamlı bir değişken olduğu söylenebilir. 
Tablo 12.

Poster Kullanma Sıklığı ve Branş Değişkeni Arasındaki iliş̧ki.

\begin{tabular}{lccccccccccc}
\hline Branş & \multicolumn{2}{c}{ Sıklıkla } & \multicolumn{2}{c}{ Arada } & \multicolumn{3}{c}{ Sadirada } & \multicolumn{2}{c}{ Hiçbir } & \multicolumn{2}{c}{ Toplam } \\
& $\mathbf{f}$ & $\mathbf{\%}$ & $\mathbf{f}$ & $\mathbf{\%}$ & $\mathbf{f}$ & $\mathbf{\%}$ & $\mathbf{f}$ & $\%$ & $\mathbf{f}$ & $\%$ \\
\hline Sınıf Öğretmeni & 25 & 33.3 & 27 & 36.0 & 21 & 28.0 & 2 & 2.7 & 75 & 100 \\
Fen Bilimleri Öğretmeni & 25 & 62.5 & 11 & 27.5 & 4 & 10.0 & 0 & 0.0 & 40 & 100 \\
Toplam & 50 & 43.5 & 38 & 33.0 & 25 & 21.7 & 2 & 1.7 & 115 & 100 \\
$\chi^{2}(3)=10.629$ & & & & & & & & & $\mathrm{p}=.014$ \\
\hline
\end{tabular}

Tablo 12'de görüldüğü üzere öğretmenlerinin poster tekniğini kullanma sıklığı ile branş değişkeni arasında yapılan Ki Kare $\left(\chi^{2}\right)$ testinde istatistiksel açıdan .05 düzeyinde anlamlı bir ilişki bulunduğu görülmektedir( $p<.05)$. Bu bulgulara dayanılarak branşın, poster tekniği kullanımında anlamlı bir değişken olduğu söylenebilir.

Tablo 13.

Anlam Çözümleme Tablosu Kullanma Sıklığı ve Branş Değişkeni Arasındaki iliş̧ki.

\begin{tabular}{|c|c|c|c|c|c|c|c|c|c|c|}
\hline \multirow[t]{2}{*}{ Branş } & \multicolumn{2}{|c|}{ Sıklıkla } & \multicolumn{2}{|c|}{$\begin{array}{l}\text { Arada } \\
\text { Sirada }\end{array}$} & \multicolumn{2}{|c|}{ Nadiren } & \multicolumn{2}{|c|}{$\begin{array}{l}\text { Hiçbir } \\
\text { Zaman }\end{array}$} & \multicolumn{2}{|c|}{ Toplam } \\
\hline & $\mathbf{f}$ & $\%$ & f & $\%$ & $\mathbf{f}$ & $\%$ & f & $\%$ & f & $\%$ \\
\hline Sınıf Öğretmeni & 30 & 40.0 & 26 & 34.7 & 16 & 21.3 & 3 & 4.0 & 75 & 100 \\
\hline Fen Bilimleri Öğretmeni & 8 & 20.0 & 14 & 35.0 & 7 & 17.5 & 11 & 27.5 & 40 & 100 \\
\hline Toplam & 38 & 33.0 & 40 & 34.8 & 23 & 20.0 & 14 & 12.2 & 115 & 100 \\
\hline$\chi^{2}(3)=15.184$ & & & & & & & & & \multicolumn{2}{|c|}{$p=.002$} \\
\hline
\end{tabular}

Tablo 13'de görüldüğü üzere öğretmenlerinin anlam çözümleme tablosu tekniğini kullanma sıklığı ile branş değişkeni arasında yapılan Ki Kare $\left(\chi^{2}\right)$ testinde istatistiksel açıdan .05 düzeyinde anlamlı bir ilişki bulunduğu görülmektedir( $p<.05)$. Bu bulgulara dayanılarak branşın, anlam çözümleme tablosu tekniği kullanımında anlamlı bir değişken olduğu söylenebilir.

Tablo 14.

Çalışma Yaprağı Kullanma Sıklığı ve Branş Değişkeni Arasındaki Ilişki.

\begin{tabular}{lccccccccccc}
\hline Branş & \multicolumn{3}{c}{ Sıklıkla } & \multicolumn{2}{c}{ Arada } & \multicolumn{3}{c}{ Sadirada } & \multicolumn{2}{c}{ Hiçbir } & \multicolumn{2}{c}{ Toplam } \\
& $\mathbf{f}$ & $\mathbf{\%}$ & $\mathbf{f}$ & $\mathbf{\%}$ & $\mathbf{f}$ & $\mathbf{\%}$ & $\mathbf{f}$ & $\mathbf{\%}$ & $\mathbf{f}$ & $\%$ \\
\hline Sınıf Öğretmeni & 57 & 76.0 & 9 & 12.0 & 7 & 9.3 & 2 & 2.7 & 75 & 100 \\
Fen Bilimleri Öğretmeni & 20 & 50.0 & 14 & 35.0 & 3 & 7.5 & 3 & 7.5 & 40 & 100 \\
Toplam & 77 & 67.0 & 23 & 20.0 & 10 & 8.7 & 5 & 4.3 & 115 & 100 \\
$\chi^{2}(3)=11.036$ & & & & & & & & & $\mathrm{p}=.012$ \\
\hline
\end{tabular}

Tablo 14'de görüldüğü üzere öğretmenlerinin çalışma yaprağı tekniğini kullanma sıklığı ile branş değişkeni arasında yapılan Ki Kare $\left(\chi^{2}\right)$ testinde istatistiksel açıdan 05 düzeyinde anlamlı bir ilişki bulunduğu görülmektedir(p< .05). Bu bulgulara dayanılarak branşın, çalışma yaprağı tekniği kullanımında anlamlı bir değişken olduğu söylenebilir. 


\section{Öğretmenlerin mezun oldukları okul türü değişkenine göre alternatif ölçme ve değerlendirme araçlarını kullanma sıklığı}

Araştırmada belirlenen alt problemlerden öğretmenlerin mezun oldukları okul türü ile alternatif ölçme değerlendirme teknikleri kullanma sıklığı arasında ilişki olup olmadığına bakıldığında ise Ki kare $\left(\chi^{2}\right)$ testi sonunda hiçbir yöntem veya teknik kullanımı sıklığı ile mezun olunan okul değişkeni arasında bir ilişki bulunmamıştır.

\section{Hizmet yılı değişkenine göre alternatif ölçme ve değerlendirme araçlarını kullanma sıklığı}

Araştırmada belirlenen alt problemlerden öğretmenlerin hizmet yılı ile alternatif ölçme değerlendirme teknikleri kullanma sıklığı arasında ilişki olup olmadığı sorusuna ait bulgular aşağıda sunulmuştur. Hizmet yılı değişkenine göre akran değerlendirmesi, öz değerlendirme ve tanılayıcı dallanmış ağaç tekniklerinin kullanım sıklığı bakımından Ki Kare $\left(\chi^{2}\right)$ testinde istatistiksel açıdan .05 düzeyinde anlamlı bir ilişki olduğundan sadece bu üç tekniğe ilişkin bulgular sunulmuştur.

Tablo 15.

Akran Değerlendirmesi Kullanma Sıklığı ve Hizmet Yılı Değişkeni Arasındaki Ilişki.

\begin{tabular}{|c|c|c|c|c|c|c|c|c|c|c|}
\hline \multirow[t]{2}{*}{ Hizmet Yılı } & \multicolumn{2}{|c|}{ Sıklıkla } & \multicolumn{2}{|c|}{$\begin{array}{l}\text { Arada } \\
\text { Sirada }\end{array}$} & \multicolumn{2}{|c|}{ Nadiren } & \multicolumn{2}{|c|}{$\begin{array}{l}\text { Hiçbir } \\
\text { Zaman }\end{array}$} & \multicolumn{2}{|c|}{ Toplam } \\
\hline & $f$ & $\%$ & $f$ & $\%$ & $f$ & $\%$ & $f$ & $\%$ & $f$ & $\%$ \\
\hline $1-10$ yıl arası & 1 & 5.3 & 8 & 25.0 & 20 & 52.6 & 13 & 50.0 & 42 & 100 \\
\hline $11-20$ yıl arası & 8 & 42.1 & 19 & 59.4 & 12 & 31.6 & 10 & 38.5 & 49 & 100 \\
\hline 21 yıl ve üzeri & 10 & 52.6 & 5 & 15.6 & 6 & 15.8 & 3 & 11.5 & 24 & 100 \\
\hline Toplam & 19 & 16.5 & 32 & 27.8 & 38 & 33.0 & 26 & 22.6 & 115 & 100 \\
\hline$\chi^{2}(3)=24.703$ & & & & & & & & & & 00 \\
\hline
\end{tabular}

Tablo 15 'de görüldüğü üzere öğretmenlerinin akran değerlendirmesi tekniğini kullanma sıklığı ile hizmet yılı değişkeni arasında yapılan Ki Kare $\left(\chi^{2}\right)$ testinde istatistiksel açıdan .05 düzeyinde anlamlı bir ilişki bulunduğu görülmektedir(p< .05). Bu bulgulara dayanılarak öğretmenlerin hizmet yılının akran değerlendirmesi tekniği kullanımında anlamlı bir değişken olduğu söylenebilir.

Tablo 16.

Öz değerlendirme kullanma sıklığı ve hizmet yılı değişkeni arasındaki ilişki.

\begin{tabular}{|c|c|c|c|c|c|c|c|c|c|c|}
\hline \multirow[t]{2}{*}{ Hizmet Yılı } & \multicolumn{2}{|c|}{ Sıklıkla } & \multicolumn{2}{|c|}{$\begin{array}{l}\text { Arada } \\
\text { Sirada }\end{array}$} & \multicolumn{2}{|c|}{ Nadiren } & \multicolumn{2}{|c|}{$\begin{array}{l}\text { Hiçbir } \\
\text { Zaman }\end{array}$} & \multicolumn{2}{|c|}{ Toplam } \\
\hline & $\mathbf{f}$ & $\%$ & $f$ & $\%$ & $f$ & $\%$ & $\mathbf{f}$ & $\%$ & $f$ & $\%$ \\
\hline 1-10 yıl arası & 7 & 17.9 & 11 & 36.7 & 14 & 48.3 & 10 & 58.8 & 42 & 100 \\
\hline $11-20$ yıl arası & 19 & 48.7 & 11 & 36.7 & 13 & 44.8 & 6 & 35.3 & 49 & 100 \\
\hline 21 yıl ve üzeri & 13 & 33.3 & 8 & 26.7 & 2 & 6.9 & 1 & 5.9 & 24 & 100 \\
\hline Toplam & 39 & 33.9 & 30 & 26.1 & 29 & 25.2 & 17 & 14.8 & 115 & 100 \\
\hline$\chi^{2}(3)=15.862$ & & & & & & & & & & 15 \\
\hline
\end{tabular}

Tablo 16 'da görüldüğü üzere öğretmenlerinin öz değerlendirme tekniğini kullanma sıklığı ile hizmet yılı değişkeni arasında yapılan Ki Kare $\left(\chi^{2}\right)$ testinde istatistiksel açıdan .05 düzeyinde anlamlı bir ilişki bulunduğu görülmektedir( $p<$.05). Bu bulgulara dayanılarak öğretmenlerin hizmet yılının, öz değerlendirme tekniği kullanımında anlamlı bir değişken olduğu söylenebilir. 
Tablo 17.

Tanılayıcı Dallanmış Ağaç Kullanma Sıklığı ve Hizmet Yılı Değişkeni Arasındaki İlişki.

\begin{tabular}{|c|c|c|c|c|c|c|c|c|c|c|}
\hline \multirow[t]{2}{*}{ Hizmet Yılı } & \multicolumn{2}{|c|}{ Sıklıkla } & \multicolumn{2}{|c|}{$\begin{array}{l}\text { Arada } \\
\text { Sirada }\end{array}$} & \multicolumn{2}{|c|}{ Nadiren } & \multicolumn{2}{|c|}{$\begin{array}{l}\text { Hiçbir } \\
\text { Zaman }\end{array}$} & \multicolumn{2}{|c|}{ Toplam } \\
\hline & $f$ & $\%$ & $f$ & $\%$ & $f$ & $\%$ & $f$ & $\%$ & $f$ & $\%$ \\
\hline $1-10$ yıl arası & 6 & 28.6 & 18 & 37.5 & 5 & 18.5 & 13 & 68.4 & 42 & 100 \\
\hline $11-20$ yıl arası & 12 & 57.1 & 17 & 35.4 & 15 & 55.6 & 5 & 26.3 & 49 & 100 \\
\hline 21 yıl ve üzeri & 3 & 14.3 & 13 & 27.1 & 7 & 25.9 & 1 & 5.3 & 24 & 100 \\
\hline Toplam & 21 & 18.3 & 48 & 41.7 & 27 & 23.5 & 19 & 16.5 & 115 & 100 \\
\hline$\chi^{2}(3)=15.808$ & & & & & & & & & \multicolumn{2}{|c|}{$p=.015$} \\
\hline
\end{tabular}

Tablo 17'de görüldüğü üzere öğretmenlerinin tanılayıcı dallanmış ağaç tekniğini kullanma sıklığı ile hizmet yılı değişkeni arasında yapılan Ki Kare $\left(\chi^{2}\right)$ testinde istatistiksel açıdan .05 düzeyinde anlamlı bir ilişki bulunduğu görülmektedir( $p<.05)$. Bu bulgulara dayanılarak öğretmenlerin hizmet yılının, tanılayıcı dallanmış ağaç tekniği kullanımında anlamlı bir değişken olduğu söylenebilir.

\section{Alternatif Ölçme Değerlendirme Tekniklerinin Uygulamasına İlişkin Bulgular}

\section{Uygulamada karşılaşılan güçlükler}

Araştırma kapsamında öğretmenlere alternatif ölçme değerlendirme tekniklerini uygulama konusunda herhangi bir güçlükle karşılaşıp karşılaşmadıkları sorulmuş ve Tablo 18'deki bulgular elde edilmiştir.

Tablo 18.

Alternatif Ölçme Değerlendirme Tekniklerini Uygulama Konusunda Herhangi Bir Güçlükle Karşılaşıyor musunuz? Bunlar nelerdir? Açıklayınız. Sorusuna iliş̧kin Verdikleri Yanıtlar.

\begin{tabular}{lccl}
\hline & $\mathbf{f}$ & $\%$ & Öğretmen İfadeleri \\
\hline Evet karşılaşıyorum & 68 & 59.0 & "Müfredatın yoğun olması, ders saatinin yetersiz olması \\
& & & $\begin{array}{l}\text { kısıtlıyor." } \\
\text { Hayır karşılaşmıyorum }\end{array}$ \\
Cevap verilmemiş & 98 & 33.0 & "Güçlükle karşılaşmıyorum." \\
Toplam & 8.0 & - \\
\hline
\end{tabular}

Öğretmenlerin büyük çoğunluğu alternatif değerlendirme tekniklerini kullanmada güçlükle karşılaştıklarını ifade etmişlerdir. 68 (\%59) öğretmen sorun yaşadığını ifade ederken, 38 (\%33) öğretmen uygulama konusunda herhangi bir sorun yaşamadıklarını belirtmişlerdir. 38 öğretmenden bir kısmı alternatif teknik kullanmadığı için sorun da olmadığını söylemiştir. 9 (\%8) öğretmen ise soruyu cevaplandırmamıştır.

Öğretmenlerin genel olarak zaman konusunda sorun yaşadıkları anlaşılmaktadır. 25 (\%22) kişi zamandan kaynaklı güçlük yaşadığını ifade etmiştir. Zamanın yanı sıra puanlama, kaynak yetersizliği, öğretmenin teknik hakkında bilgi eksikliği, kontrol edememe, bireysel farklılıklar, hazır bulunuşluk, velilerden kaynaklı sorunlar, sınıf mevcudunun kalabalık oluşu gibi farklı güçlükler yaşadıklarını belirtmişlerdir.

$\mathrm{K}_{23}$ (S.Ö. 21 yıl ve üzeri):

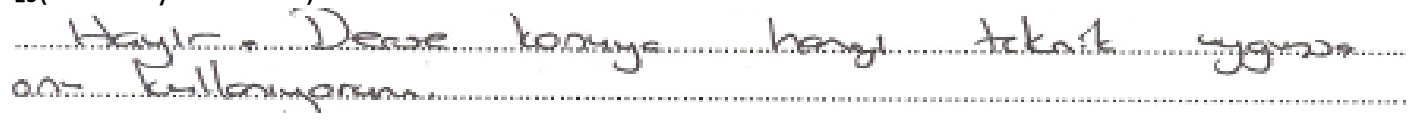


$\mathrm{K}_{10}$ (S.Ö. 21 yıl ve üzeri):

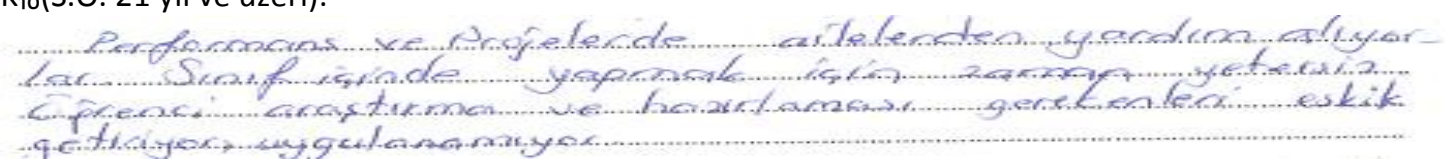

K 46 (F.T.Ö. 11-20 yıl arası):

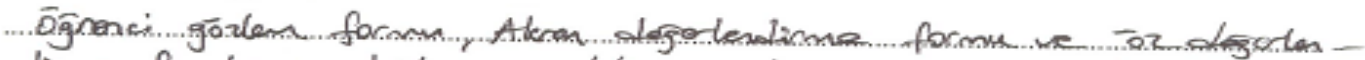

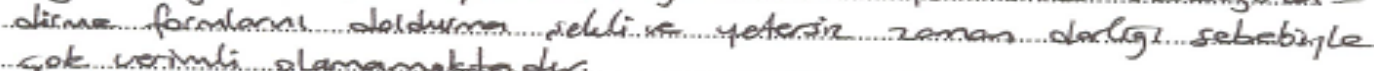

$\mathrm{K}_{82}(\mathrm{~S} .0 ̈ .21$ yıl ve üzeri):

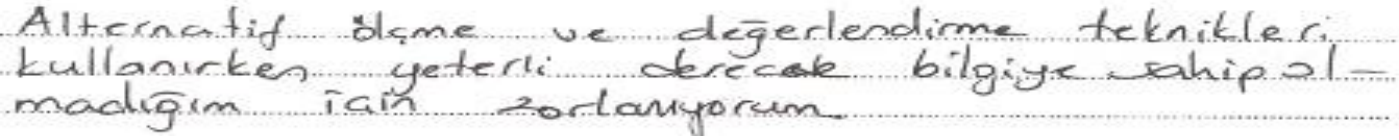

\section{Uygulama sonrası yapılanlar}

Öğretmenlere ölçme değerlendirme sonunda öğrencilerde eksik ya da hatalı buldukları konularla ilgili olarak geri dönüt sağlamada ne gibi uygulamalar yaptıkları sorulmuş ve Tablo 19'daki bulgular elde edilmiştir.

Tablo 19.

"Ölçme Değerlendirme Sonunda Öğrencilerde Eksik ya da Hatalı Bulduğunuz Konularla Ilgili Olarak Geri Dönüt Sağlamada Ne Gibi Uygulamalar Yapıyorsunuz? " Sorusuna ilişskin Verdikleri Yanıtlar.

\begin{tabular}{lccl}
\hline & f & \% & Öğretmen ifadeleri \\
\hline Konu tekrarı yapma & 86 & 74.8 & $\begin{array}{l}\text { "Konu tekrarı yaparak eksik olan kısımlarla ilgili daha } \\
\text { çok örnek çözüyorum." }\end{array}$ \\
Yeniden değerlendirme & 20 & 17.4 & "Yeni bir değerlendirme yaparım." \\
Anında düzeltme yapma & 5 & 4.3 & "Ders anında eksiğini göstererek anlatıyorum." \\
Veli görüşmesi & 3 & 2.6 & "Veli ile görüşürüm." \\
Cevap verilmemiş & 1 & 0.9 & - \\
Toplam & 115 & 100 & \\
\hline
\end{tabular}

Öğretmenlerin büyük çoğunluğu konu tekrarı yaptıklarını ifade etmişlerdir. 62 (\%54) öğretmen konuyu tekrar ettiklerini ifade ederken nasıl bir şekilde uygulama yaptıklarını belirtmemişlerdir. 24 (\%21) öğretmen de farklı yöntem ve teknik ile yeniden dersi işleme yoluna gittiklerini açıklamışlardır. Toplamda öğretmenlerin büyük çoğunluğu 86 (\%74.8) konuyu tekrar ettiklerini belirtmişlerdir. 20 (\%17.4) öğretmen ise farklı yollarla yeniden bir değerlendirme yaptıklarını belirtmişlerdir. Öğretmenlerden sadece 5 (\%4.3) kişi anında düzeltmeler yaptıklarını ifade etmişlerdir. 3 (\%2.6) öğretmen ise değerlendirme sonuçlarını veli ile görüştüğünü söylemiştir. 1 (\%0.9) öğretmen ise soruyu cevaplandırmamıştır.

K

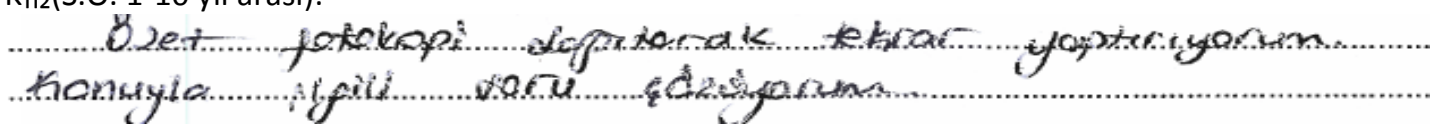


$\mathrm{K}_{115}$ (S.Ö. 11-20 yıl arası):

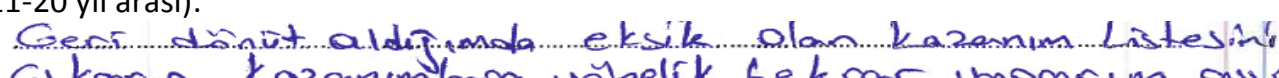

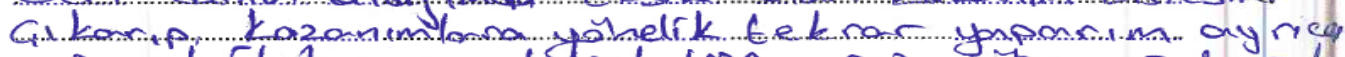

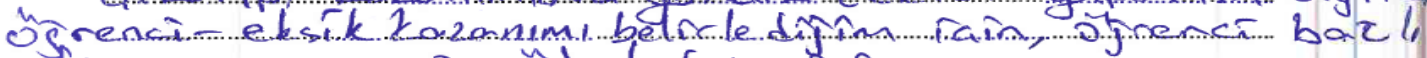

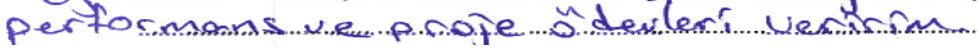

$\mathrm{K}_{83}$ (S.Ö. 21 yıl ve üzeri):

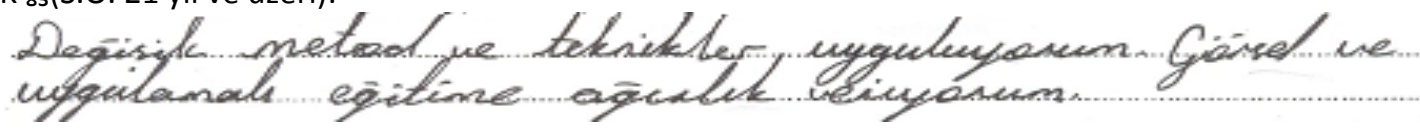

K ${ }_{97}($ S.Ö. 1-10 yıl arası):

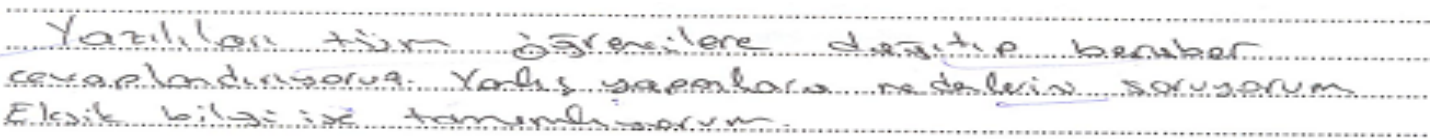

\section{Alternatif ve geleneksel yöntemlere eğilim}

Öğretmenlere geleneksel ölçme değerlendirme ve alternatif ölçme değerlendirme yaklaşımlarından hangisine daha eğilimli oldukları sorulmuş ve Tablo 20'deki bulgular elde edilmiştir.

Tablo 20.

"Geleneksel Ölçme Değerlendirme ve Alternatif Ölçme Değerlendirme Yaklaşımlarından Hangisine Kendinizin Daha Eğilimli Olduğunuzu Hissetmektesiniz?” Sorusuna Iliş̧kin Verdikleri Yanıtlar.

\begin{tabular}{|c|c|c|c|}
\hline & $f$ & $\%$ & Öğretmen ífadeleri \\
\hline $\begin{array}{l}\text { Geleneksel tekniklere } \\
\text { eğilimlivim }\end{array}$ & 51 & 44.4 & "Zaman yetersiz olduğu için geleneksel teknikler \\
\hline $\begin{array}{l}\text { Alternatif tekniklere } \\
\text { eğilimliyim }\end{array}$ & 38 & 33.0 & $\begin{array}{l}\text { "Alternatife yatkınım. Çünkü öğrencinin bilgisini daha } \\
\text { iyi ölçtüğüne inanıyorum." }\end{array}$ \\
\hline Eşit uzaklıktayım & 15 & 13.1 & "Zamana göre ikisinide kullanırım." \\
\hline Cevap verilmemiş & 11 & 9.5 & - \\
\hline Toplam & 115 & 100 & \\
\hline
\end{tabular}

Öğretmenlerden 51 (\%44.4) kişi geleneksel tekniklere eğilimli olduğunu, 38 (\%33) öğretmen alternatif tekniklere eğilimli olduğunu belirtmektedir. 15 (\%13.1) öğretmen ise her ikisine eşit uzaklıkta olduklarını ifade etmişlerdir. 11 (\%9.5) öğretmen de bu soruyu cevaplandırmamıştır.

Geleneksel tekniklere eğilimin sebebi olarak öğretmenlerden 6 kişi SBS sınav sisteminin buna zorladığını söylemişlerdir. Ayrıca 9 öğretmen ise daha objektif puanlama yapabildiklerinden geleneksel tekniklere eğilimli olduklarını ifade etmişlerdir. Bunların dışında zaman, alternatif teknikleri bilmeme, geleneksel tekniklere yatkınlık, öğrencilerin hazır bulunuşluğu gibi sebeplerden bahsetmişlerdir.

Alternatif tekniklere eğilimin sebebi olarak öğretmenler öğrenciler için ilgi çekici oluşu, bireysel farklılıkları göz önünde bulundurması, detaylı ölçüm sağlaması, öğrencilerin kendilerini daha iyi ifade edebilmelerini sağlayan ve gelişime ayak uydurmanın gerekli olduğu gibi sebeplerden bahsetmişlerdir.

$\mathrm{K}_{79}($ S.Ö. 21 yıl ve üzeri):

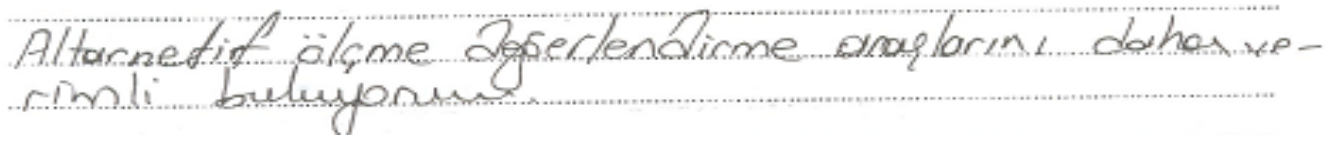



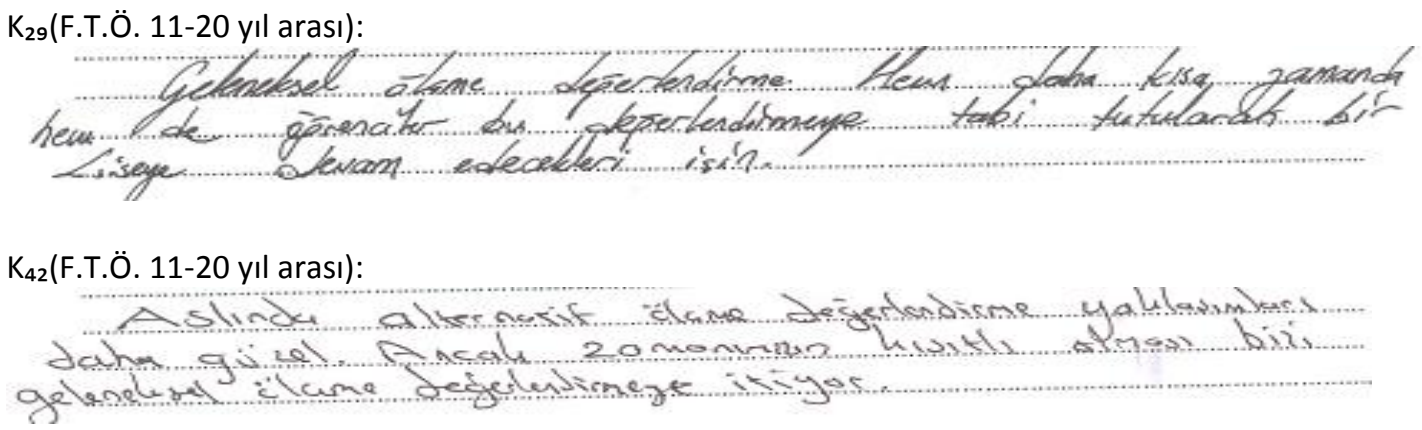

$K_{84}($ S.Ö. 21 yıl ve üzeri):

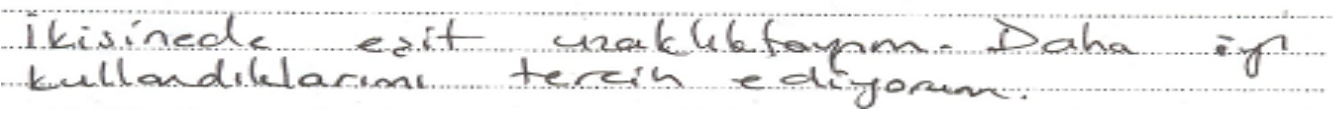

\section{Sonuç, Tartışma ve Öneriler}

Bu çalışmada sınıf öğretmeni ve fen bilimleri öğretmenlerinin alternatif ölçme değerlendirme tekniklerini hangi sıklıkta kullandıkları belirlenmiş ve alternatif ölçme teknikleri ile ilgili görüşleri ve bu teknikleri uygulama durumları araştırılmışır. Bu araştırmada öğretmenlerin en çok kullandıkları alternatif ölçme tekniklerin çalışma yaprağı ve performans değerlendirme olduğu tespit edilmiştir. Performans değerlendirmenin Milli Eğitim Bakanlığı tarafından zorunlu tutulması en çok kullanılan alternatif teknik olmasının sebebi olabilir. En sık kullanılan tekniğin performans değerlendirme olduğu bulgusu farklı araştırmalarla paralellik göstermektedir (Anıl ve Acar, 2008; Kanatlı, 2008; Kaya, vd., 2012; Okur ve Azar, 2011; Yeşilyurt, 2012; Şimşek, 2011). Performans değerlendirmeden sonra öğretmenlerin kullanmayı en çok tercih ettikleri teknik bulmacadır.

Öğretmenlerin en az sıklıkta kullandıkları alternatif ölçme tekniklerinin akran değerlendirmesi, yapılandırılmış grid, portfolyo ve tanılayıcı dallanmış ağaç olduğu tespit edilmiştir. En az kullanılan alternatif tekniklerden birinin akran değerlendirme olduğu sonucu literatürde yer alan diğer çalışmalarla paralellik göstermektedir (Adanalı ve Doğanay, 2010; Çelikkaya, vd., 2010). Yapılandıııııı̧ grid tekniği ile ilgili literatürde öğretmenlerin bilgi eksikliği bulunduğu ve buna bağlı olarak az kullanıldığı tespit edilen çalışmalar bulunmaktadır. Yapılandırılmıs grid tekniğinin az kullanıldığı bulgusu farklı araştırmalarla paralellik göstermektedir (Kanatlı, 2008; Karamustafaoğlu, vd., 2012; Kaya, vd., 2012; Okur, 2008; Okur ve Azar, 2011; Şimşek, 2011). Portfolyo kullanımı öğretmenlerin az kullandığı tekniklerden biri olarak gözükmektedir. Oysa Sandford ve Hsu (2013) araştırmalarında alternatif değerlendirmenin kullanımı ve uygulanmasını büyük bir çözüm olarak görmeseler de portfolyo kullanımının değerlendirmede farklı bir etki yaratarak revizyon yarattığını belirtmişlerdir. Tanılayıcı dallanmış ağacın az kullanılan bir teknik olması farklı araştırma bulguları ile benzerlik göstermektedir (Kaya, vd., 2012; Karamustafaoğlu, vd., 2012; Okur, 2008;Okur ve Azar, 2011; Sağlam, vd., 2009; Şimşek, 2011).

Yapılandırılmış grid ve tanılayıcı dallanmış ağaç tekniğinin kullanımının az olmasının sebebi olarak bazı araştırmalar öğretmenlerin tekniklerle ilgili bilgi eksikliğinden kaynaklandığı bulgusuna ulaşmışlardır (Akçadağ, 2010; Sağlam-Arslan, vd., 2008; Yala, 2011; Yapalak, 2009). Oysa Karahan (2007)'ye göre yapılandırılmış grid ve tanılayıcı dallanmış ağaç tekniğinin kullanımının öğrenci başarısını olumlu bir şekilde arttırdığı tespit edilmiştir. Bazı araştırmalar bu tekniklerle ilgili olarak öğretmenlerin bilgi eksikliği olmasının hizmet içi eğitim kurslarının yetersizliğinden kaynaklandığını tespit etmişlerdir (Anıl ve Acar, 2008; Çelikkaya, vd., 2010; Çoruhlu, vd., 2009). Nitekim yeni teknikler ile ilgili verimli bir hizmet içi eğitim alınmasının ölçme değerlendirmede etkililiği arttırdığı yönünde araştırma sonuçları bulunmaktadır (Çoruhlu, vd., 2008; Şenel, 2008). Ancak, geçen zaman sürecinde yapılan araştırmalarda ve bu araştırmada hala benzer bulgulara ulaşılıyor olması yapılan hizmet içi ve hizmet öncesi uygulamaların 
yetersiz kaldığına işaret ediyor olabilir. Bununla birlikte, öğretmenlerin bu tür uygulamalara zaman kaybı gözü ile bakmaları, bu teknikleri benimsememeleri, ya da fayda sağlamadığını düşünmeleri de bu sonucu etkileyen sebepler arasında sayılabilir. Nitekim bu çalışmaya katılan bazı öğretmenler bu yöndeki görüşlerini ifade etmişlerdir. Ayrıca bazı öğretmenler sınav sisteminin kendilerini geleneksel yöntemleri daha fazla kullanmaya ittiğini belirtmişlerdir.

Öğretmenlerin cinsiyet değişkenine göre alternatif ölçme değerlendirme kullanmaları ile ilgili yapılan Ki Kare $\left(\chi^{2}\right)$ testi analizine göre portfolyo, kavram haritası, gösteri ve görüşme tekniklerinde anlamlı farklılık göstermektedir. Bayanların bu teknikleri daha sık kullandıkları tespit edilmiştir. Bayan öğretmenlerin alternatif ölçme değerlendirme tekniklerini kullanmada daha olumlu görüş içinde oldukları farklı araştırmalarda tespit edilmiştir (Karamustafaoğlu, vd., 2012; Okur ve Azar, 2011).

Öğretmenlerin branş değişkenine göre alternatif ölçme değerlendirme kullanmaları ile ilgili yapılan Ki Kare $\left(\chi^{2}\right)$ testi analizine göre rubrik, portfolyo, akran değerlendirmesi, öz değerlendirme, poster, anlam çözümleme tablosu ve çalışma yaprağı tekniklerinde anlamlı farklılık göstermektedir. Öğretmenlerin branşlarına göre alternatif ölçme değerlendirme tekniklerini kullanma durumları incelendiğinde sınıf öğretmenlerinin poster dışındaki değerlendirme tekniklerini fen bilimleri öğretmenlerinden daha sık kullandıkları görülmektedir. Bununlar birlikte fen bilimleri dersi öğretmenlerinin poster tekniğini çok daha sık kullandıkları belirlenmiştir. Bunun sebebi ilköğretim 1. kademe düzeyindeki öğretmen ve öğrenci kaynak kitaplarında bu teknikleri barındıran pek çok uygulama yer alması ve öğretmenlerin bunları hazır olarak bulabilmesi olabilir. Ayrıca bazı teknikler işlenilen konuların mahiyetine bağlı olarak ilköğretim ikinci kademe sınıflarında kullanıma uygun olmayabilir.

$\mathrm{Bu}$ araştırmada öğretmenlerin mezun oldukları okul türü değişkenine göre alternatif ölçme değerlendirme kullanmaları ile ilgili yapılan Ki Kare $\left(\chi^{2}\right)$ testi analizine göre anlamlı bir farklılık bulunmamıştır. Bazı diğer araştırmalar da benzer şekilde öğretmenlerin mezun oldukları okul türü ile alternatif ölçme değerlendirme tekniklerini kullanmaları arasında anlamlı bir fark olmadığını tespit etmiştir (Kaya, vd., 2012; Karamustafaoğlu, vd., 2012; Okur ve Azar, 2011). Öte yandan Kanatlı, (2008) eğitim fakültesinden farklı bir fakülteden mezun olan öğretmenlerin alternatif ölçme değerlendirmeye daha olumlu baktıklarını tespit etmiştir.

Öğretmenlerin hizmet yılı değişkenine göre alternatif ölçme değerlendirme kullanmaları ile ilgili yapılan Ki Kare $\left(\chi^{2}\right)$ testi analizine göre akran değerlendirmesi, öz değerlendirme ve tanılayıcı dallanmış ağaç teknikleri anlamlı farklılık göstermektedir. Karamustafaoğlu vd. (2012) ile Kanatı (2008)'e göre öğretmenlerin kıdemlerine göre az kıdemli öğretmenlerin alternatif ölçme değerlendirme teknikleri kullanımına daha olumlu baktıkları tespit edilmiştir. Öte yandan ise bazı araştırmalar kıdemi fazla olan öğretmenlerin alternatif ölçme değerlendirme teknikleri bilme ve uygulama düzeylerinin kıdemi az olan öğretmenlere göre daha yüksek olduğunu tespit etmişlerdir (Kaya, vd., 2012; Okur, 2008; Okur ve Azar, 2011). Bu araştırma da aynı sonucu desteklemektedir. Bu sonuç, hizmet yılı daha fazla olan öğretmenlerin yeni teknikleri uygulamada ve genel olarak, öz yeterlik inançlarııı daha güçlü olmasından kaynaklanıyor olabilir.

Alternatif ölçme ve değerlendirmede öğretmenlerin çoğunluğu 68 (\% 59) güçlükle karşıaşıılarını ifade etmişlerdir. Genel olarak öğretmenler karşılaştıkları güçlüklerin zaman yetersizliği, sınıfların kalabalık oluşu, objektif olarak not verememek, velilerin olumsuz etkileri, teknikle ilgili bilgi yetersizliği olduğunu belirtilmişlerdir. Farklı araştırmalar bu bulguları destekler niteliktedir (Anıl ve Acar,2008; Baki ve Birgin, 2002; Okur, 2008; Orhan, 2007; Sağlam, vd., 2009; Yeşilyurt, 2012). Benzer şekilde Aksu (2008) araştırmasında öğretmenlerin büyük kısmının alternatif ölçme değerlendirme tekniklerinin uzun zaman aldığını ve bu yüzden kullanımının verilen zaman içinde oldukça zor olduğunu ifade ettiklerini belirtmiştir. Nitekim konuya ilişkin olarak Ercan ve Altun (2005) yapmış oldukları araştırmada, öğretmenlere alternatif değerlendirme tekniklerinin uygulanabilirliği sorulmuş ve öğretmenlerin \%100'ü bu tekniklerin hepsini her zaman kullanmadığını belirtmişlerdir. Katılımcıların $\% 75^{\prime} i$ alternatif 
değerlendirme tekniklerini zor bulduklarını dile getirmişlerdir. Katılımcıların \%45'i alternatif değerlendirme tekniklerini sınıfların kalabalık olmasından dolayı uygulayamadıklarını belirtmişlerdir (Akt: Gömleksiz ve Bulut, 2007).

Alternatif ölçme ve değerlendirme ile ilgili literatür incelendiğinde öğretmenlerin geleneksel ölçme değerlendirme tekniklerine yatkınlıkları ile ilgili bulgular göze çarpmaktadır (Anıl ve Acar, 2008; Çelikkaya, vd., 2010; Çoruhlu, vd., 2009; Kirman, 2008; Kocaarslan, 2012; Okur, 2008; Yeşilyurt, 2012). $\mathrm{Bu}$ çalışma kapsamında elde edilen bulgulara göre ise öğretmenlerin geleneksel yaklaşımın doğrultusundaki uygulamalardan kısmen vazgeçmiş oldukları gözükmektedir.

$\mathrm{Bu}$ çalışmanın bulgularından hareketle araştırmacılara, öğretmenlerin alternatif ölçme ve değerlendirme tekniklerini kullanma durumlarıyla ilgili gözlem ya da görüşme yöntemleri de kullanılarak, nitel araştırmalar yapılması, böylece alandaki sorunların derinlemesine bir şekilde incelenerek çözüm önerileri sunulması faydalı olabilir. Araştırma kapsamında elde edilen bulgular doğrultusunda öğretmenlerin en az kullandıkları tekniklerin neden az kullanıldığına ilişkin derinlemesine araştırmalar yapılması yararlı olabilir.

Öğretmenler alternatif ölçme ve değerlendirme ile ilgili olarak karşılaştıkları güçlükler konusunda bilgi yetersizlikleri olduğunu belirtmişlerdir. Yine aynı şekilde bazı öğretmenler bilgi yetersizliği sebebiyle geleneksel ölçme değerlendirme tekniklerini eğilimli olduklarını ifade etmişlerdi. Bu nedenle bilgi yetersizliği konusunda verimli olacak şekilde hizmet içi eğitimler düzenlenmesi ve öğretmenlerin bu tekniklere bakış açılarının olumlu yönde değiştirilmesine çalışılması önerilebilir.

\section{Kaynakça}

Adanalı, K. \& Doğanay, A. (2010). Beşinci sınıf sosyal bilgiler öğretiminin alternatif ölçme değerlendirme etkinlikleri açısından değerlendirilmesi. Çukurova Üniversitesi Sosyal Bilimler Enstitüsü Dergisi, 19(1), 271-292.

Akçadağ, T. (2010). Öğretmenlerin ilköğretim programındaki yöntem, teknik ölçme ve değerlendirme konularına ilişkin eğitim ihtiyaçları. Ahmet Yesevi Üniversitesi Mütevelli Heyet Başkanlığı, 53, 29-50.

Aksu, H. (2008). A study on the determination of secondary school mathematics teachers 'views on alternative assessment, Humanity and Social Sciences Journal,3(2), 89-96.

Anıl, D. \& Acar, M. (2008). Sınıf öğretmenlerinin ölçme değerlendirme sürecinde karşılaştıkları sorunlara ilişkin görüşleri. Yüzüncü Yıl Üniversitesi Eğitim Fakültesi Dergisi, 5(11), 44- 66.

Baki, A. \& Birgin, O. (2002). Matematik eğitiminde alternatif bir değerlendirme olarak bireysel gelişim dosyası uygulama, V. Ulusal Fen Bilimleri ve Matematik Eğitimi Kongresi Bildiri Kitabı, 913-920, Ankara: Devlet Kitapları Müdürlüğü Basımevi.

Balcı, A. (2004). Sosyal bilimlerde araştırma yöntem teknik ve ilkeler. Ankara: Pegem A Yayıncılık.

Çalışkan, H. \& Kaşıksız, Y. (2010). The application of traditional and alternative assessment and evaluation tools by teachers in social studies. Procedia Social and Behavioral Sciences, 2, 4152-4156.

Çelikkaya, T., Karakuş, U., \& Öztürk, D. T. (2010). Sosyal bilgiler öğretmenlerinin ölçme- değerlendirme araçlarını kullanma düzeyleri ve karşılaştıkları sorunlar. Ahi Evran Üniversitesi Eğitim Fakültesi Dergisi, 11(1), 57-76.

Çepni, S. \& Çoruhlu T. Ş. (2010). Alternatif ölçme ve değerlendirme tekniklerine yönelik hazırlanan hizmet içi eğitim kursundan öğretime yansımalar. Pamukkale Üniversitesi Eğitim Fakültesi Dergisi, Sayı 28, 117-128.

Çoruhlu, Ş. T., Nas, E,S., \& Çepni, S. (2008). Fen ve teknoloji öğretmenlerinin alternatif ölçme değerlendirme tekniklerini kullanmada karşılaştıkları problemler: Trabzon örneği. Necatibey Eğitim Fakültesi Elektronik Fen ve Matematik Eğitimi Dergisi (EFMED), 2(2), 1-22. 
Çoruhlu, Ş. T., Nas, E.S., \& Çepni, S. (2009). Fen ve teknoloji öğretmenlerinin alternatif ölçme değerlendirme tekniklerini kullanmada karşılaştıkları problemler: Trabzon örneği. Yüzüncü yıl Üniversitesi Eğitim Fakültesi Dergisi, 6(1), 122-141.

Gömleksiz, M. N. \& Bulut, ì. (2007). Yeni fen ve teknoloji dersi öğretim programının uygulamadaki etkililiğinin değerlendirilmesi. Hacettepe Üniversitesi Eğitim Fakültesi Dergisi, 32, 76-88.

Kanatlı, F. (2008). Alternatif ölçme değerlendirme teknikleri konusunda sınıf öğretmenlerinin görüşlerinin değerlendirilmesi. Unpublished master's thesis, Mustafa Kemal Üniversitesi, Sosyal Bilimler Enstitüsü, Hatay.

Karahan, U. (2007). Alternatif ölçme ve değerlendirme metodlarından grid, tanılayıcı dallanmış ağaç ve kavram haritalarının biyoloji öğretiminde uygulanması. Unpublished master's thesis, Gazi Üniversitesi, Eğitim Bilimleri Enstitüsü, Ankara.

Karasar, N. (2005). Bilimsel araştırma yöntemi. Ankara: Nobel Yayın Dağıtım.

Karamustafaoğlu, S., Çağlak, A., \& Meşeci B. (2012). Alternatif ölçme değerlendirme araçlarına ilişkin sınıf öğretmenlerinin öz yeterlilikleri. Amasya Üniversitesi Eğitim Fakültesi Dergisi, 1(2), 167-179.

Kaya, A., Balay, R. \& Göçen, A. (2012). Öğretmenlerin alternatif ölçme ve değerlendirme tekniklerine ilişkin bilme, uygulama ve eğitim ihtiyacı düzeyleri. International Journal of Human Sciences, 9(2), 1303-5134.

Kirman, A. (2008). Ilköğretim 6., 7. ve 8. sınıf fen bilgisi dersinde, geleneksel ve alternatif ölçme ve değerlendirme sistemlerinin, başarı testleri yapılarak karşılaştırılması. Unpublished master's thesis, Kafkas Üniversitesi, Fen Bilimleri Enstitüsü, Kars.

Kocaarslan, M. (2012). Tanılayıcı dallanmış ağaç tekniği ve ilköğretim 5. Sınıf fen ve teknoloji dersi maddenin değişimi ve tanınması adlı ünitede kullanımı. Mustafa Kemal Üniversitesi Sosyal Bilimler Enstitüsü Dergisi, 9(18), 269-279.

MEB. (2005). İlköğretim fen ve teknoloji dersi öğretim programı ve kılavuzu (Taslak Basım). Ankara: Devlet Kitapları

MEB. (2006). ilköğretim sosyal bilgiler dersi öğretim programı. Ankara: Devlet Kitapları

Nelson, L. \& Drake, F. (1997). Enhancing reflective practice through alternative assessment. Journal of Research in Rural Education, 13 (1), 47-56.

Okur, M. \& Azar, A. (2011). Fen ve teknoloji dersinde kullanılan alternatif ölçme tekniklerine ilişkin öğretmen görüşleri. Kastamonu Eğitim Dergisi, 19(2), 387- 400.

Okur, M. (2008). 4. ve 5. sınıf öğretmenlerinin fen ve teknoloji dersinde kullanılan alternatif ölçme ve değerlendirme tekniklerine ilişkin görüşlerinin belirlenmesi. Unpublished master's thesis, Karaelmas Üniversitesi, Sosyal Bilimler Enstitüsü, Zonguldak.

Orhan, A. (2012). Alternatif ölçme ve değerlendirme etkinliklerinin 6. sınıf fen ve teknoloji dersi yaşamımızdaki elektrik ünitesindeki öğrenci başarısına etkisi. Unpublished master's thesis, Ahi Evran Üniversitesi, Fen Bilimleri Enstitüsü, Kırşehir.

Orhan, A. T. (2007). Fen eğitiminde alternatif ölçme ve değerlendirme yöntemlerinin ilköğretim öğretmen adayı, öğretmen ve öğrenci boyutu dikkate alınarak incelenmesi. Unpublished doctoral dissertation, Gazi Üniversitesi, Eğitim Bilimleri Enstitüsü, Ankara.

Öncü, H. (2009). Ölçme ve değerlendirmede yeni bir yaklaşım: portfolyo değerlendirme, Türkiye Sosyal Araştırmalar Dergisi, 13(1), 103-130.

Özçelik, D.A., (2010). Öğrenme öğretim ve değerlendirme ile ilgili bir sınıflama. Ankara:Pegem Yayıncılık.

Sağlam-Arslan, A., Avcı, N., \& İyibil, Ü. (2008). Fizik öğretmen adaylarının alternatif ölçme değerlendirme yöntemlerini algılama düzeyleri. Dicle Üniversitesi Ziya Gökalp Eğitim Fakültesi Dergisi, 11, 115-128. 
Sağlam-Arslan, A., Devecioğlu-Kaymakçı, Y., \& Arslan, S. (2009). Alternatif ölçme değerlendirme tekniklerinde karşılaşılan problemler: Fen ve teknoloji öğretmenleri örneği. On Dokuz Mayıs Üniversitesi Eğitim Fakültesi Dergisi, 28, 1-12.

Sandford, B. A. \& Hsu, C. C. (2013). Alternative assessment and portfolios: review, reconsider, and revitalize. International Journal of Social Science Studies, 1(1), 215-221.

Şenel, T. (2008). Fen ve teknoloji öğretmenleri için alternatif ölçme ve değerlendirme tekniklerine yönelik bir hizmet içi eğitim programının etkililiğinin araştırılması. Unpublished master's thesis, Karadeniz Teknik Üniversitesi, Fen Bilimleri Enstitüsü, Trabzon.

Şimşek, N. (2011). Sosyal bilgiler dersinde alternatif ölçme değerlendirme araçlarının kullanılması: nitel bir çalışma. Fırat Üniversitesi Sosyal Bilimler Dergisi, 21 (1), 149-168.

Vurkaya, G. (2010). Alternatif değerlendirme etkinliklerinin fen ve teknoloji dersinde kullanılmasının öğrencilerin başarı ve tutumlarına etkisi. Unpublished master's thesis, Kocaeli Üniversitesi, Fen Bilimler Enstitüsü, Kocaeli.

Yapalak, S. (2009). Fen bilgisi öğretmen adaylarının alternatif ölçme ve değerlendirme yeterliklerinin tespiti ve geliştirilmesine yönelik bir eylem araştırması. Unpublished master's thesis, Gazi Üniversitesi, Eğitim Bilimler Enstitüsü, Ankara.

Yayla, G. (2011). Fen ve teknoloji öğretmenlerinin tecrübeleriyle alternatif ölçme ve değerlendirme yaklaşımlarına yönelik öz yeterlilikleri arasındaki ilişki. 2nd International Conference on New Trends in Education and Their Implications, Antalya.

Yeşilyurt, E. (2012). Fen ve teknoloji dersinde kullanılan ölçme değerlendirme yöntemleri ve karşılaşılan güçlükler. Turkish Studies- International Periodical for The Languages, Literature and History of Turkish or Turkic, 7(2), 1183-1205.

Yıldırım, A. \& Şimşek, H. (2005). Sosyal bilimlerde nitel araştırma yöntemleri. Ankara: Seçkin Yayıncılık. 
Nida BÜYÜKTOKATLI ve Şule BAYRAKTAR - Pegem Eğitim ve Öğretim Dergisi, 4(1) 2014, 103-126 